\title{
Molecular genetics and targeted therapy of WNT-related human diseases (Review)
}

\author{
MASUKO KATOH $^{1}$ and MASARU KATOH ${ }^{2}$ \\ ${ }^{1}$ M\&M Medical BioInformatics, Tokyo 113-0033; ${ }^{2}$ Department of Omics Network, \\ National Cancer Center, Tokyo 104-0045, Japan
}

Received April 3, 2017; Accepted July 12, 2017

DOI: $10.3892 /$ ijmm.2017.3071

\begin{abstract}
Canonical WNT signaling through Frizzled and LRP5/6 receptors is transduced to the $\mathrm{WNT} / \beta$-catenin and WNT/stabilization of proteins (STOP) signaling cascades to regulate cell fate and proliferation, whereas non-canonical WNT signaling through Frizzled or ROR receptors is transduced to the WNT/planar cell polarity (PCP), WNT/G protein-coupled receptor $(\mathrm{GPCR})$ and $\mathrm{WNT} /$ receptor tyrosine kinase (RTK) signaling cascades to regulate cytoskeletal dynamics and directional cell movement. WNT/ $\beta$-catenin signaling cascade crosstalks with RTK/SRK and GPCR-cAMP-PKA signaling cascades to regulate $\beta$-catenin phosphorylation and $\beta$-catenindependent transcription. Germline mutations in WNT signaling molecules cause hereditary colorectal cancer, bone diseases, exudative vitreoretinopathy, intellectual disability syndrome and PCP-related diseases. APC or CTNNB1 mutations in colorectal, endometrial and prostate cancers activate the $\mathrm{WNT} / \beta$-catenin signaling cascade. $R N F 43, Z N R F 3, R S P O 2$ or $R S P O 3$ alterations in breast, colorectal, gastric, pancreatic and other cancers activate the WNT/ $\beta$-catenin, WNT/STOP and other WNT signaling cascades. ROR1 upregulation in B-cell leukemia and solid tumors and ROR2 upregulation in melanoma induce invasion, metastasis and therapeutic resistance through Rho-ROCK, Rac-JNK, PI3K-AKT and YAP signaling activation. WNT signaling in cancer, stromal and immune cells dynamically orchestrate immune evasion and antitumor immunity in a cell context-dependent manner. Porcupine (PORCN), RSPO3, WNT2B, FZD5, FZD10, ROR1, tankyrase and $\beta$-catenin are targets of anti-WNT signaling therapy, and ETC-159, LGK974, OMP-18R5 (vantictumab), OMP-54F28 (ipafricept), OMP-131R10 (rosmantuzumab), PRI-724 and UC-961 (cirmtu-
\end{abstract}

Correspondence to: Dr Masaru Katoh, Department of Omics Network, National Cancer Center, 5-1-1 Tsukiji, Chuo-Ward, Tokyo 104-0045, Japan

E-mail: mkatoh-kkr@umin.ac.jp

Key words: Alzheimer's disease, angiogenesis, cancer stem cells, epithelial-to-mesenchymal transition, FGF, myeloid-derived suppressor cells, Notch, regulatory T cells, tumor microenvironment, WNT5A zumab) are in clinical trials for cancer patients. Different classes of anti-WNT signaling therapeutics are necessary for the treatment of APC/CTNNB1-, RNF43/ZNRF3/RSPO2/RSPO3- and ROR1-types of human cancers. By contrast, Dickkopf-related protein 1 (DKK1), SOST and glycogen synthase kinase $3 \beta$ (GSK3 $\beta$ ) are targets of pro-WNT signaling therapy, and antiDKK1 (BHQ880 and DKN-01) and anti-SOST (blosozumab, BPS804 and romosozumab) monoclonal antibodies are being tested in clinical trials for cancer patients and osteoporotic post-menopausal women. WNT-targeting therapeutics have also been applied as reagents for in vitro stem-cell processing in the field of regenerative medicine.

\section{Contents}

1. Introduction

2. Hereditary colorectal cancer and various types of sporadic cancers

3. Intellectual disability syndrome, Alzheimer's disease and bipolar disorder

4. Bone diseases

5. Vascular diseases

6. Human diseases related to core PCP components

7. Other genetic diseases

8. Therapeutics targeting WNT signaling cascades

9. Conclusion

\section{Introduction}

The WNT family of secreted glycoproteins consists of WNT1 (INT1), WNT2, WNT2B (WNT13), WNT3 (INT4), WNT3A, WNT4, WNT5A, WNT5B, WNT6, WNT7A, WNT7B, WNT8A, WNT8B, WNT9A (WNT14), WNT9B (WNT14B), WNT10A, WNT10B, WNT11 and WNT16 (1). WNT signals are transduced through the Frizzled family comprising seventransmembrane receptors (FZD1, FZD2, FZD3, FZD4, FZD5, FZD6, FZD7, FZD8, FZD9 and FZD10) and single-transmembrane co-receptors (LRP5, LRP6, ROR1 and ROR2) to initiate the canonical and non-canonical signaling cascades $(2,3)$.

Canonical WNT signaling through Frizzled and LRP5/6 receptors promotes $\beta$-catenin-dependent transcription of $\mathrm{TCF} / \mathrm{LEF}$ target genes (WNT/ $\beta$-catenin signaling) (4) and 
$\beta$-catenin-independent de-repression of FOXM1, NRF2 (NFE2L2), YAP and other proteins [WNT/stabilization of proteins (STOP) signaling] $(5,6)$ (Fig. 1). By contrast, noncanonical WNT signaling through Frizzled or ROR receptors activates Dishevelled-dependent Rho-ROCK and Rac-JNK cascades [WNT/planar cell polarity (PCP) signaling] (7); $\mathrm{G}$ protein-dependent calcineurin-NFAT, CAMK2-NLK and PKC cascades [WNT/G protein-coupled receptor (GPCR) signaling] (2); and receptor tyrosine kinase (RTK)-dependent PI3K-AKT (8) and YAP/TAZ (9) cascades (WNT/RTK signaling) (Fig. 1). WNT signals regulate self-renewal, metabolism, survival, proliferation and epithelial-to-mesenchymal transition (EMT) of target cells (10-13), and crosstalk with FGF, Hedgehog, Notch and transforming growth factor- $\beta$ (TGF- $\beta$ ) signals (14-16). As the intracellular and intercellular WNT signaling networks orchestrate embryogenesis and homeostasis, genetic alterations in WNT signaling molecules are involved in the pathogenesis of various types of human cancers and noncancerous diseases (Fig. 2).

Next-generation sequencing that produces huge amounts of genomic, epigenomic and transcriptomic data (17-20) and cell-based technologies, such as induced pluripotent stem cells (iPSCs) (21-23), direct reprogramming to somatic stem/progenitor cells (24) and CRISPR/Cas9-mediated genome editing $(25,26)$, have been elucidating the mechanistic involvement of the WNT signaling cascades in human pathophysiology and opening up new therapeutics avenues for human diseases.

We carried out the Human WNTome and Post-WNTome Projects to construct a platform of medical WNT research in the late 1990s and early 2000s (1,2,7 and references therein). Despite amazing progress in basic studies of WNT signaling and genetics, there is still a huge gap that must be addressed before WNT-targeted therapy for patients can be applied. A mechanistic understanding of the pathogenesis of WNT-related diseases is necessary to address the gap between basic research and clinical application. Here, human genetics and genomics of WNT-related diseases will be reviewed (Table I), and then, clinical application of WNT signaling-targeted therapy using small-molecule compounds, human/humanized monoclonal antibodies $(\mathrm{mAb})$ and chimeric antigen receptor-modified $\mathrm{T}$ cells (CAR-T) will be discussed.

\section{Hereditary colorectal cancer and various types of sporadic cancers}

Germline mutations in the $A P C$ gene occur in patients with familial adenomatous polyposis, which is characterized by innumerable colorectal adenomas and predisposition to colorectal cancer (27), whereas germline mutations in the AXIN2 and RNF43 genes occur in patients with oligodontiacolorectal cancer syndrome (28) and sessile serrated polyposis cancer syndrome (29), respectively. Hereditary colorectal cancer is caused by loss-of-function mutations in the $A P C$, AXIN2 and RNF43 genes (Fig. 2).

Somatic $A P C$ mutations preferentially occur in non-hypermutated or conventional colorectal cancers, and somatic $A X I N 2$ and RNF43 mutations preferentially occur in hypermutated or microsatellite-unstable colorectal cancers $(30,31)$. Gain-of-function mutations in the CTNNB1 gene encoding $\beta$-catenin (S33C, S37F/Y, T41A or S45F/P), EIF3E-RSPO2 fusions and PTPRK-RSPO3 fusions also occur in sporadic colorectal cancers $(31,32)$. Loss-of-function $A P C$ mutations, gain-of-function $C T N N B 1$ mutations or loss-of-function RNF43 or ZNRF3 mutations have also been reported in breast cancer (33), gastric cancer (34), hepatocellular carcinoma (35), lung cancer (36), pancreatic cancer (37), prostate cancer (38) and uterine corpus endometrial carcinoma (39). Various types of human cancers are driven by somatic alterations in the canonical WNT signaling molecules, such as APC, AXIN2, $\beta$-catenin, RNF43, RSPO2 and RSPO3 (Fig. 2).

In the adult intestine, WNT2B and WNT3 are secreted from pericryptal cells and Paneth cells, respectively, and transduce canonical WNT signaling through FZD7 for the maintenance of crypt base columnar (CBC) stem cells $(40,41)$. Binding of canonical WNTs to the FZD and LRP5/6 receptors induces formation of the FZD-Dishevelled-AXIN-LRP5/6 complex and release of $\beta$-catenin from its degradation complex consisting of APC, AXIN, casein kinase 1 (CK1) and glycogen synthase kinase $3 \beta$ (GSK3 $\beta$ ), which results in nuclear translocation of stabilized $\beta$-catenin and subsequent transcriptional activation of TCF/LEF target genes, such as $A X I N 2$, cyclin D1 (CCNDI), FZD7 and c-Myc (MYC) (Fig. 3). Gain-of-function mutations in the CTNNB1 gene, as well as loss-of-function mutations in the $A P C$ and $A X I N 2$ genes, activate the canonical WNT/ $\beta$-catenin signaling cascade that regulates self-renewal, survival, proliferation and differentiation of tumor cells.

RNF43 and ZNRF3 are transmembrane-type E3-ubiquitin ligases that downregulate cell-surface FZD receptors through ubiquitylation and attenuate canonical and non-canonical WNT signaling, whereas RSPO2 and RSPO3 are RNF43/ZNRF3 ligands that de-repress FZD receptors from RNF43/ZNRF3mediated degradation and enhance WNT signaling $(3,42)$. Lossof-function mutations in the RNF43 and ZNRF3 genes, as well as EIF3E-RSPO2 and PTPRK-RSPO3 fusions, potentiate the WNT/ $\beta$-catenin signaling cascade and $\beta$-catenin-independent WNT signaling cascades (Fig. 4).

$A P C$ and $C T N N B 1$ alterations in conventional colorectal cancers induce WNT-independent activation of the $\beta$-catenin signaling cascade, whereas RNF43, RSPO2 and RSPO3 alterations in non-conventional colorectal cancers can activate the WNT/ $\beta$-catenin and other WNT signaling cascades (Fig. 4). To target different classes of genetic alterations in the WNT signaling molecules, several types of anti-WNT signaling therapeutics have been developed and are described later.

\section{Intellectual disability syndrome, Alzheimer's disease and bipolar disorder}

$\beta$-catenin, encoded by the $C T N N B 1$ gene, is a scaffold protein that interacts with WNT signaling components (including APC, AXIN, BCL9 and TCF/LEF), adhesion molecules (such as E-cadherin, $\mathrm{N}$-cadherin and $\alpha$-catenin) and epigenetic/transcriptional regulators (for example, CBP, p300, EZH2 and SMARCA4/BRG1) $(43,44)$. Cadherin-bound $\beta$-catenin is stable and involved in the maintenance of cell-cell adhesion, whereas cytoplasmic free $\beta$-catenin is degraded in the proteasome through priming phosphorylation at $\mathrm{S} 45$ by CK1, following phosphorylation at S33, S37 and T41 by GSK3 $\beta$, 


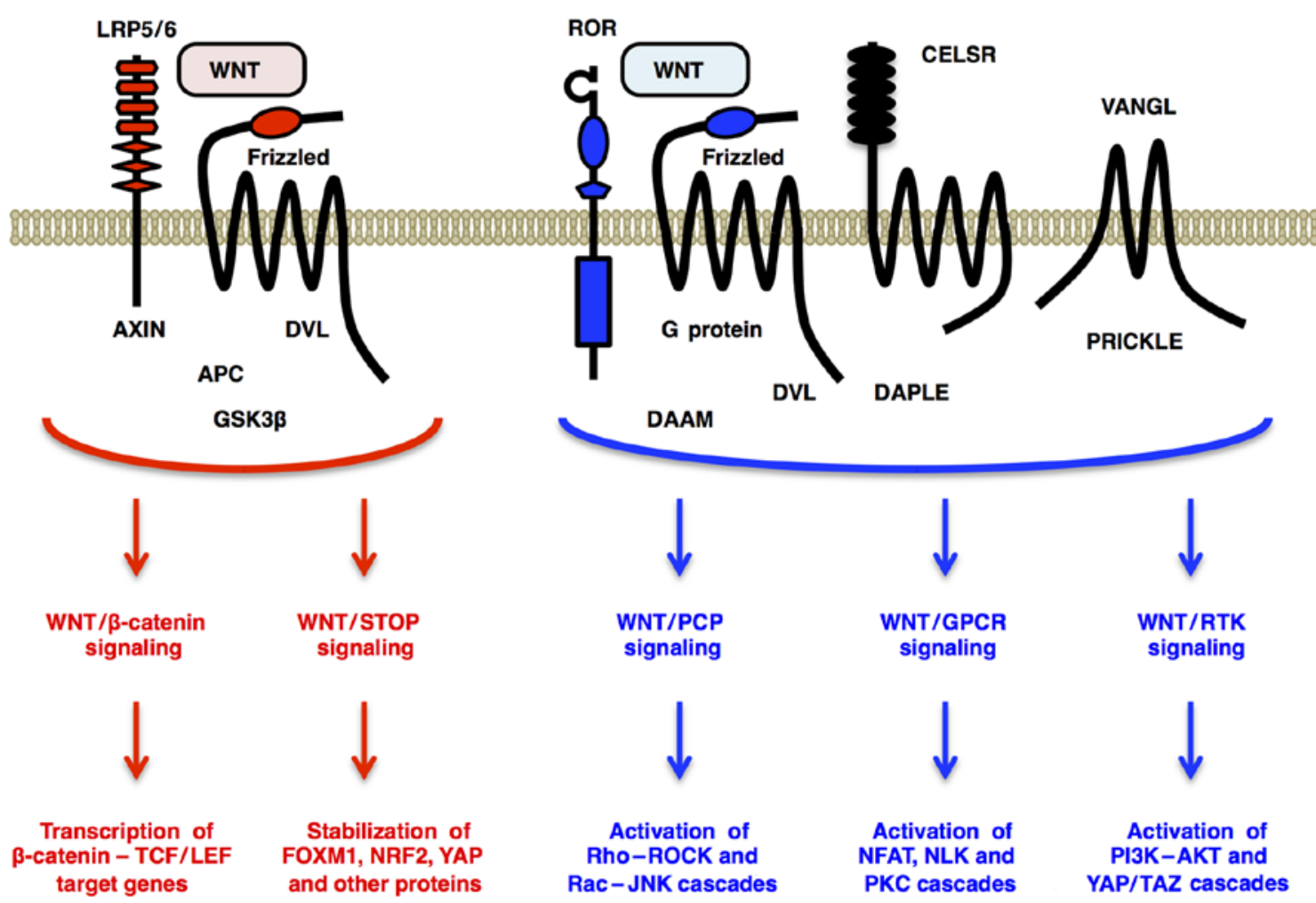

Figure 1. Overview of WNT signaling cascades. Canonical WNT signaling through Frizzled and LRP5/6 receptors promotes $\beta$-catenin-dependent transcription of $C C N D 1, F Z D 7, M Y C$ and other genes (WNT/ $\beta$-catenin signaling) and $\beta$-catenin-independent stabilization of FOXM1, NRF2 (NFE2L2), YAP and other proteins (WNT/STOP signaling). Non-canonical WNT signaling through Frizzled or ROR receptors activates DVL-dependent Rho-ROCK and Rac-JNK cascades (WNT/PCP signaling), G protein-dependent calcineurin-NFAT, CAMK2-NLK and PKC cascades (WNT/GPCR signaling) and RTK-dependent PI3K-AKT and YAP/TAZ cascades (WNT/RTK signaling). Context-dependent WNT signaling through canonical and non-canonical signaling cascades regulates cell fate and proliferation, tissue or tumor microenvironment and whole-body homeostasis. GPCR, G protein-coupled receptor; PCP, planar cell polarity; RTK, receptor tyrosine kinase; STOP, stabilization of proteins.

and subsequent poly-ubiquitylation at K19 by E3 ubiquitin ligase (45). Canonical WNT signaling activation leads to stabilization and nuclear translocation of cytoplasmic $\beta$-catenin as mentioned above (Fig. 3). By contrast, activation of BCR-ABL, FLT3, KIT, SRC and RET tyrosine kinases $(43,46-48)$ leads to release and nuclear translocation of cadherin-bound $\beta$-catenin through phosphorylation at Y654 and subsequent PKA-dependent phosphorylation at S675 (49). $\beta$-catenin is located at the crossroad of canonical WNT, tyrosine kinase and GPCR-cAMP-PKA signaling cascades for the regulation of cell adhesion, cell fate and cell functions (Fig. 3).

De novo loss-of-function mutations in the CTNNBI gene (for example, Q309X, S425fs and R515X) have been reported in patients with intellectual disability and other common features, such as microcephaly, speech disorder, truncal hypotonia and distal hypertonia (50). A loss-offunction CTNNB1 mutation (P706fs) has also been reported in a patient presenting with intellectual disability, autism-like features, exudative vitreoretinopathy and lipomyelomeningocele (a closed form of neural tube defect) (51). WNT/ $\beta$-catenin signals promote symmetrical and asymmetrical divisions of neural stem cells for their expansion and generation of neural progenitor cells, respectively, regulate proliferation and differentiation of neural progenitor cells in a context- dependent manner, and thus, maintain synaptic function (52). Therefore, loss-of-function mutations in the CTNNB1 gene give rise to intellectual disability syndrome through impaired expansion and differentiation of neural stem/progenitor cells during embryonic, perinatal and postnatal brain development (Fig. 2).

WNT/ $\beta$-catenin signals are also necessary for adult neurogenesis or neuronal plasticity and synaptic maintenance (53). As WNT/ $\beta$-catenin signaling induces the expression of the NeuroD1 transcription factor to promote neurogenesis in the hippocampus and olfactory bulb, Dickkopf-related protein 1 (Dkk1) upregulation in the hippocampus of SAMP8 mice is associated with decreased canonical WNT signaling and neuronal loss (54) and Wnt3 downregulation in the olfactory bulb of streptozotocin-induced diabetic rats is associated with impaired odor discrimination, cognitive dysfunction and increased anxiety (55). Dkk1 induction in the hippocampus of iDkk1 transgenic mice causes synaptic loss and memory defects through canonical WNT/ $\beta$-catenin signaling inhibition and non-canonical WNT/RhoA-ROCK signaling activation, whereas Dkk1 repression reverts the Alzheimer's disease-like phenotypes in the iDkk1 transgenic mice (56). WNT/ $\beta$-catenin signaling also induces expression of the REST silencing factor to protect neurons from oxidative stress and aggregated 


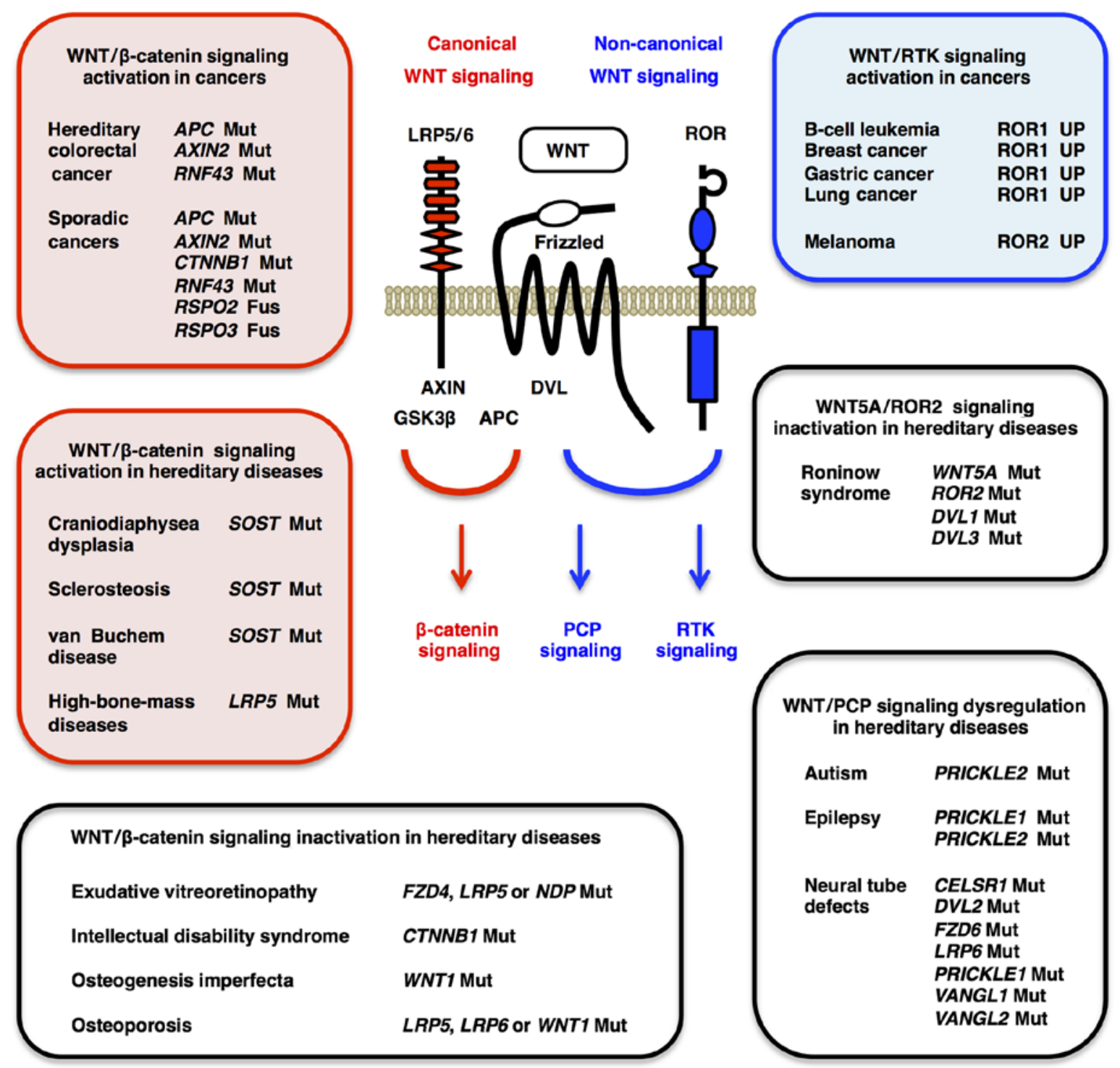

Figure 2. WNT signaling dysregulation in cancer and non-cancerous diseases. Canonical WNT/ $\beta$-catenin signaling cascade is aberrantly activated in hereditary colorectal cancer and various types of sporadic cancers owing to genetic alterations in the APC, AXIN2, CTNNB1, RNF43, RSPO2 and RSPO3 genes, and also in hereditary osteoblastic diseases owing to SOST and LRP5 mutations (red boxes). The WNT/B-catenin signaling cascade is downergulated in intellectual disability syndrome owing to $C T N N B 1$ loss-of-function mutations, in familial exudative vitreoretinopathy owing to loss-of-function mutations in the FZD4 and LRP5 genes and in osteoporosis-associated syndromes owing to LRP5, LRP6 and WNT1 loss-of-function mutations (open box). By contrast, noncanonical WNT/RTK signaling cascade is aberrantly activated in B-cell leukemia and solid tumors as a result of ROR1 upregulation (blue box). Non-canonical WNT/PCP signaling cascade is dysregulated in PCP-related hereditary diseases, such as autism, epilepsy, neural tube defects and Robinow syndrome owing to mutations in the CELSR1, DVL1, DVL2, DVL3, FZD6, PRICKLE1, PRICKLE2, ROR2, VANGL1, VANGL2 and WNT5A genes (open boxes). Genetic alterations in the WNT signaling molecules affect multiple WNT signaling cascades. For example, RNF43, RSPO2 and RSPO3 alterations activate WNT/ $\beta$-catenin and other WNT signaling cascades, whereas loss-of-function LRP5 mutations inactivate the WNT/ $\beta$-catenin signaling cascade and reciprocally activate the WNT/PCP signaling cascade. PCP, planar cell polarity; RTK, receptor tyrosine kinase.

misfolded protein in aging brains; however, neuronal nuclear REST is lost in patients with Alzheimer's disease, frontotemporal dementia and Lewy-body dementia (57). By contrast, impaired canonical WNT/ $\beta$-catenin signaling is involved in the pathogenesis of bipolar disorder through defective resilience to chronic stress (58). WNT7B downregulation in CXCR4 ${ }^{+}$ neural progenitor cells derived from bipolar-disease iPSCs is associated with a reduced proliferation potential, and canonical WNT/ $\beta$-catenin signaling activation using GSK3 inhibitor (CHIR99021) restores the proliferation deficits (59), which explains the rationale why another GSK3 inhibitor, lithium, is utilized for the treatment of patients with bipolar disorder. Together, these facts indicate that impaired WNT/ $\beta$-catenin signaling is involved in the pathogenesis of neuropsychiatric diseases, such as Alzheimer's disease and bipolar disorder.

\section{Bone diseases}

Bone homeostasis is maintained by mesenchymal stem cells that generate osteoblasts, osteoblast-derived osteocytes and other types of mesenchymal cells, as well as hematopoietic stem cells that give rise to monocytes, monocyte-derived osteoclasts and other types of blood cells. Canonical WNT/ $\beta$-catenin signaling through Frizzled and LRP5/6 receptors promotes RUNX2-dependent osteoblastic differentiation of mesenchymal stem or progenitor cells $(60,61)$. Canonical 


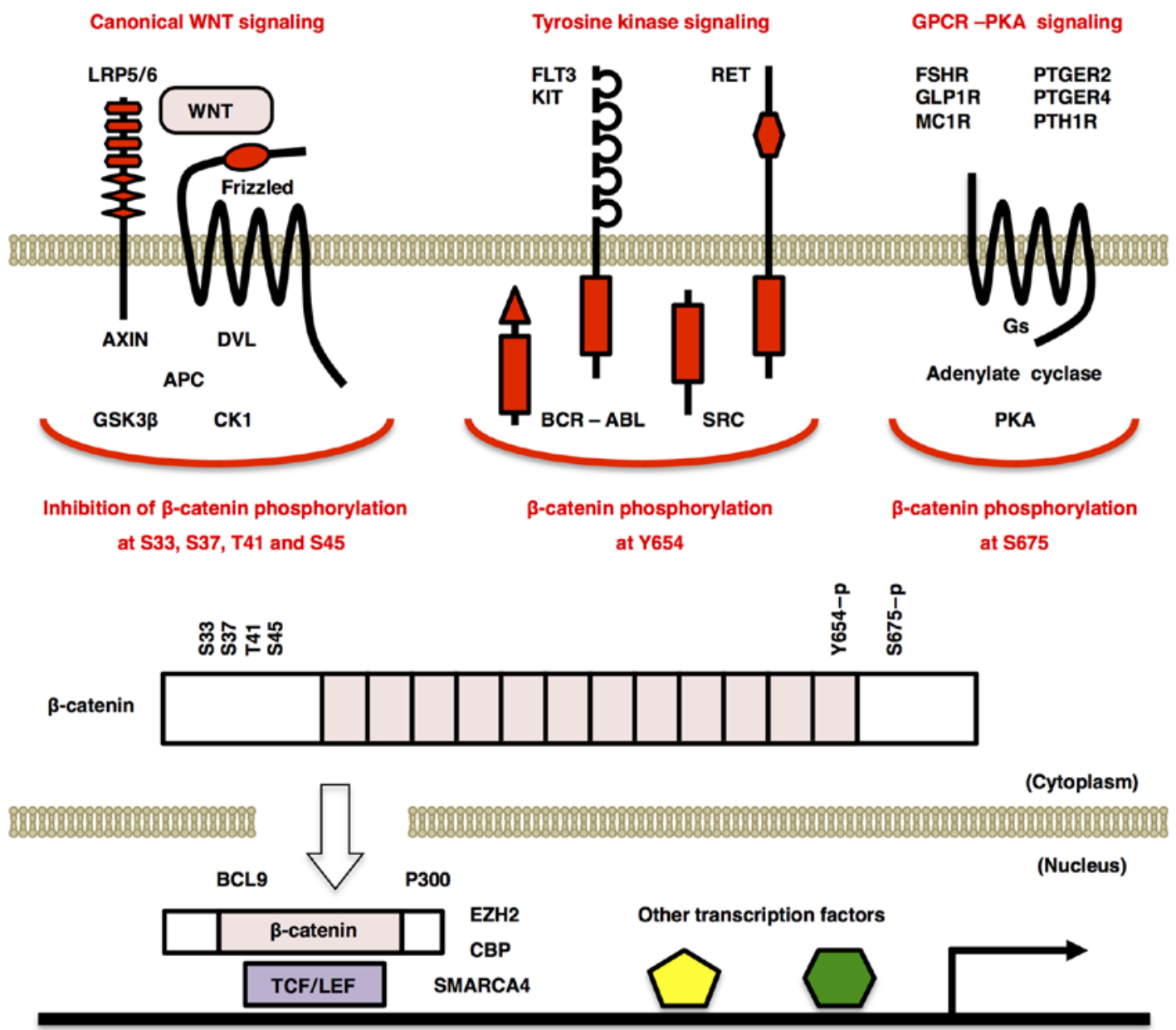

Cell context - dependent upregulation of $\beta$-catenin target genes

\begin{tabular}{|c|c|c|c|c|c|}
\hline $\begin{array}{l}\text { AXIN2 } \\
\text { DKK1 }\end{array}$ & $\begin{array}{l}\text { LEF1 } \\
\text { NOTUM }\end{array}$ & $\begin{array}{l}\text { ASCL2 } \\
\text { CD44 }\end{array}$ & $\begin{array}{l}\text { NEUROD1 } \\
\text { SNAIL }\end{array}$ & $\begin{array}{l}\text { FGF20 } \\
\text { JAG1 }\end{array}$ & $\begin{array}{l}\text { CCND1 } \\
\text { MYC }\end{array}$ \\
\hline$F Z D 7$ & & LGR5 & & VEGF & \\
\hline $\begin{array}{l}\text { WNT } \\
\text { reg }\end{array}$ & $\begin{array}{l}\text { naling } \\
\text { on }\end{array}$ & $\begin{array}{r}\text { Ce } \\
\text { deter }\end{array}$ & $\begin{array}{l}\text { ate } \\
\text { nation }\end{array}$ & $\begin{array}{l}\text { Cross-talk } \\
\text { signaling }\end{array}$ & Prolife \\
\hline
\end{tabular}

Figure 3. $\beta$-catenin at the crossroad of WNT, tyrosine kinase and GPCR-cAMP-PKA signaling cascades. WNT/ $\beta$-catenin signaling activation induces stabilization and nuclear translocation of $\beta$-catenin and upregulation of $\beta$-catenin-TCF/LEF target genes. By contrast, activation of BCR-ABL, FLT3, KIT, SRC or RET tyrosine kinases and GPCR-mediated PKA activation induce $\beta$-catenin phosphorylation at Y654 and S675, respectively, which also promotes nuclear translocation of $\beta$-catenin and $\beta$-catenin-dependent transcription. FSHR (275), GLP1R (276), MC1R (277), PTGER2/EP2 (278,279), PTGER4/EP4 (278,280) and PTH1R (281) are GPCRs that are reported to induce cAMP-dependent PKA activation and subsequent $\beta$-catenin activation. AXIN2, CCND1, DKK1, FGF20, FZD7, JAG1, MYC, NEUROD1 and NOTUM are representative targets of the WNT/ $\beta$-catenin signaling cascade; however, $\beta$-catenin target genes are context-dependently upregulated owing to additional transcriptional regulation by the tyrosine kinase and PKA signaling cascades. GPCR, G protein-coupled receptor; PKA, protein kinase A, DKK1, Dickkopf-related protein 1.

WNT signaling in osteoblast-lineage cells upregulates BMP2, and then BMP2 signaling through BMPR1A upregulates WNT7A/10B to synergistically potentiate osteoblastogenesis and bone formation $(62,63)$. BMP2 signaling in osteoblastlineage cells also upregulates the canonical WNT inhibitors DKK1 and sclerostin (SOST) to turn off canonical WNT signaling for the fine-tuning of bone mass $(64,65)$. By contrast, parathyroid hormone (PTH) signaling through PTH1R in osteoblast-lineage cells downregulates SOST to promote bone formation and upregulates RANK ligand (RANKL) to induce osteoclastic differentiation of osteoclast progenitors (66). Non-canonical WNT5A signaling through ROR2 in osteoclast progenitors upregulates the RANK receptor to promote
RANKL-induced osteoclastogenesis and bone resorption (67). WNT signaling cascades crosstalk with BMP, cytokine and PTH signaling cascades in a context-dependent manner to precisely control the balance of bone formation and resorption.

Aberrant canonical WNT signaling activation gives rise to bone-formation phenotypes (Fig. 2). Loss-of-function mutation or deletion in the SOST gene occurs in patients with sclerosing skeletal dysplasias, such as craniodiaphyseal dysplasia (68), sclerosteosis (69) and van Buchem disease (70). Heterozygous mutations in the N-terminal signal peptide of SOST (V21M/L) are detected in patients with craniodiaphyseal dysplasia, the most severe form of SOST-defective disease, which is characterized by massive hyperostosis with leonine face 


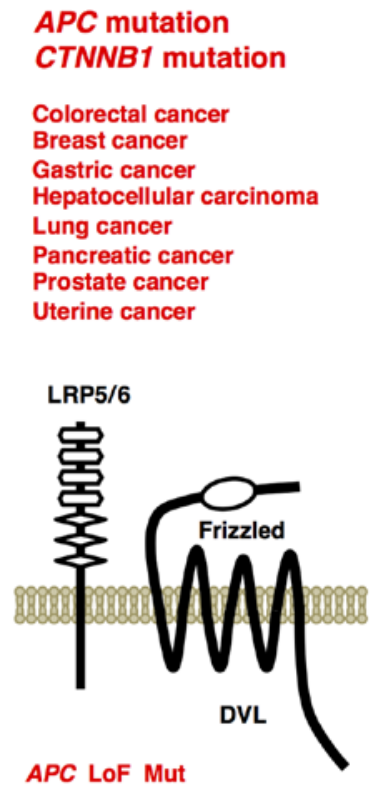

CTNNB1 GoF Mut

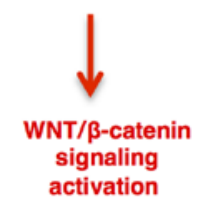

Investigational drugs

$\beta$-catenin inhibitors
RNF43 mutation

ZNRF3 mutation

RSPO2 fusion

RSPO3 fusion

RSPO3 up-regulation
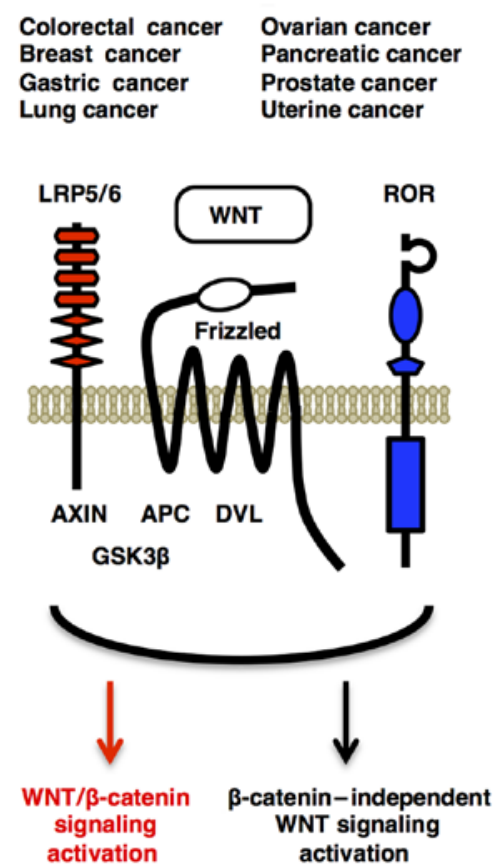

activation

activation
ROR1 upregulation

$$
\begin{aligned}
& \text { B-cell leukemia } \\
& \text { CLL } \\
& \text { ALL with } t(1 ; 19)
\end{aligned}
$$

\section{Solid tumors}

Breast cancer

Gastric cancer

Lung cancer
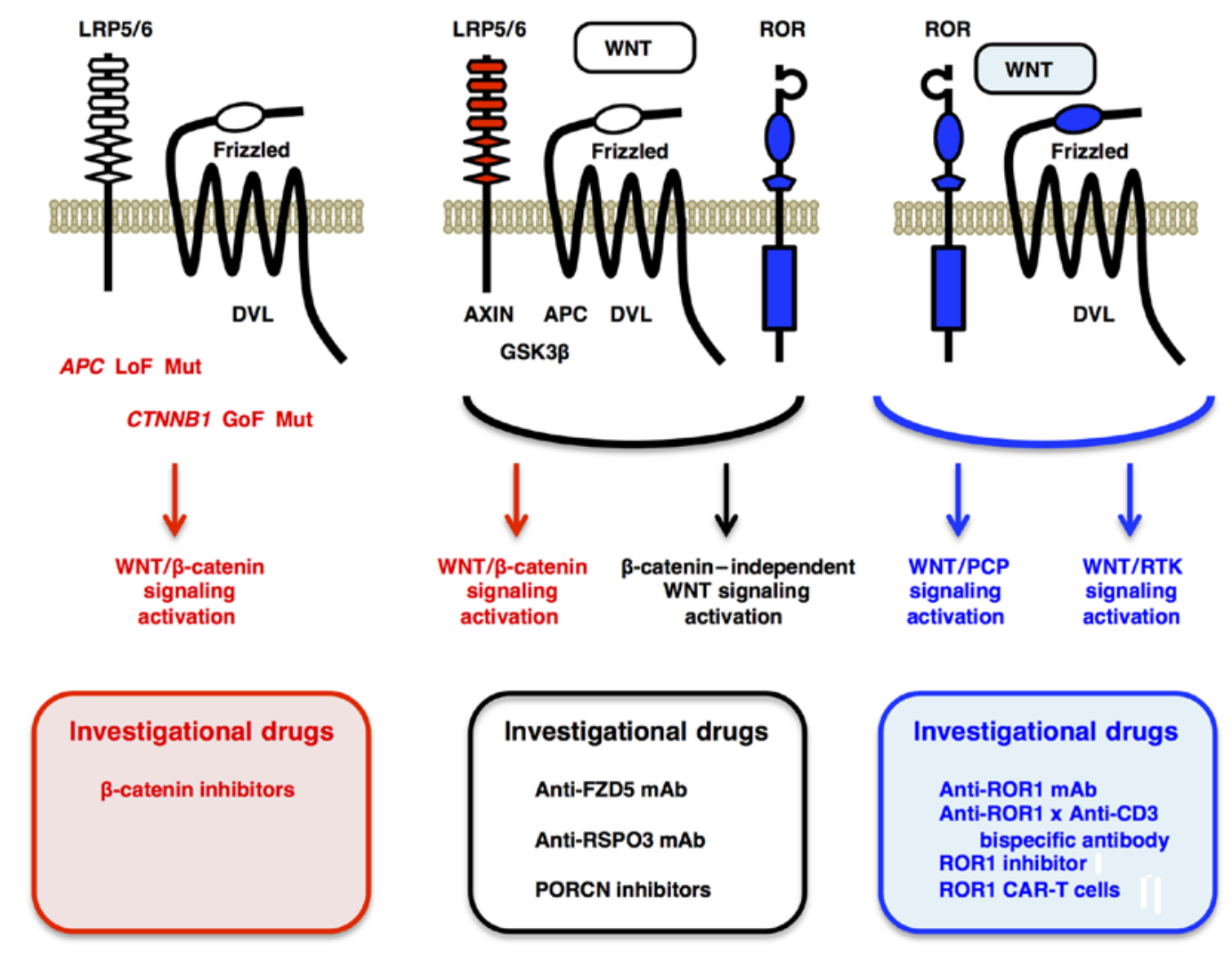

Figure 4. Mutations, downstream signaling and therapeutics of WNT-related human cancers. (Left) Loss-of-function APC mutations and gain-of-function CTNNB1 mutations in human cancers, such as colorectal cancer, breast cancer and uterine cancer (uterine corpus endometrial carcinoma), lead to ligand-independent activation of the WNT/ $\beta$-catenin signaling cascade, which can be treated with $\beta$-catenin inhibitors in preclinical model animal experiments. (Middle) Loss-of-function $R N F 43$ or ZNRF3 mutations, RSPO2/3 fusions and RSPO3 upregulation in colorectal cancer, breast cancer, pancreatic cancer and other cancers activate the WNT/ $\beta$-catenin signaling cascade as well as $\beta$-catenin-independent WNT signaling cascades, such as WNT/STOP and WNT/PCP signaling cascades. This type of cancers can be treated with anti-FZD5 mAb, anti-RSPO3 mAb or PORCN inhibitors. (Right) ROR1 upregulation in B-cell leukemia and solid tumors gives rise to WNT/PCP and WNT/RTK signaling activation, which can be treated with anti-ROR1 mAb, anti-ROR1 $\mathrm{x}$ anti-CD3 bispecific antibodies, ROR1 inhibitor and ROR1 CAR-T cells. PCP, planar cell polarity; ALL, acute lymphoblastic leukemia; CAR-T, chimeric antigen receptor-modified T cells; CLL, chronic lymphocytic leukemia; GoF, gain-of-function; LoF, loss-of-function; mAb, monoclonal antibody; Mut, mutation; RTK, receptor tyrosine kinase; STOP, stabilization of proteins; PORCN, porcupine.

and craniofacial foraminal stenosis. Homozygous missense mutation $(\mathrm{Q} 24 \mathrm{X})$ and enhancer deletion in the SOST gene are detected in patients with sclerosteosis and van Buchem disease, respectively, which are characterized by gigantism, facial palsy and hearing loss. Sclerosteosis is a severe form of SOST-defective disease frequently presenting with syndactyly, whereas van Buchem disease is a mild form of SOST-defective disease without syndactyly. By contrast, LRP5 mutations in the first $\beta$-propeller domain (for example, D111Y, G171R, A214T and $\mathrm{A} 242 \mathrm{~T}$ ) have been reported in patients with high-bonemass diseases, such as van Buchem disease type 2, endosteal hyperostosis and osteopetrosis type 1 (71). LRP5 mutations in the first $\beta$-propeller domain are gain-of-function mutations, as SOST and DKK1 bind to the first $\beta$-propeller domain of LRP5 to inhibit canonical WNT signaling $(64,65)$. Loss-of-function
SOST mutations and gain-of-function LRP5 mutations cause bone-formation phenotypes in patients with sclerosing skeletal dysplasias and high-bone-mass diseases, respectively.

Defects in canonical WNT signaling and/or aberrant activation of non-canonical WNT signaling cause bone-resorption phenotypes (Fig. 2). Osteoporosis is characterized by low bone mineral density (BMD), deteriorated bone quality and susceptibility to fracture, whereas osteogenesis imperfecta is a prenatal-onset osteoporotic disease characterized by brittle bones $(72,73)$. Homozygous loss-of-function mutations in the LRP5 gene (such as R428X, E485X, D490fs and D718X) have been detected in patients with osteoporosis-pseudoglioma syndrome, which is characterized by osteoporosis and eye phenotypes (exudative vitreoretinopathy and susceptibility to blindness) (74). Heterozygous loss-of-function mutation in 
Table I. Germline and somatic alterations in WNT signaling molecules in human diseases.

\begin{tabular}{|c|c|c|c|c|}
\hline Gene & Function & Germline & Somatic & (Refs.) \\
\hline$A P C$ & $\beta$-catenin degradation & Hereditary colorectal cancer & Cancer & $(27)$ \\
\hline AXIN2 & $\beta$-catenin degradation & Hereditary colorectal cancer & Cancer & $(28,30)$ \\
\hline CELSR1 & Core PCP component & Neural tube defects & & $(115)$ \\
\hline$C T N N B 1$ & $\beta$-catenin & Intellectual disability syndrome & Cancer & $(30,50)$ \\
\hline$D A P L E$ & $\beta$-catenin degradation & Hydrocephalus & & $(170)$ \\
\hline DVL1 & Intracellular WNT signaling & Robinow syndrome & & $(120)$ \\
\hline DVL2 & Intracellular WNT signaling & Neural tube defects & & $(115)$ \\
\hline DVL3 & Intracellular WNT signaling & Robinow syndrome & & $(120)$ \\
\hline FZD4 & WNT receptor & Exudative vitreoretinopathy & & $(91)$ \\
\hline FZD5 & WNT receptor & Ocular coloboma & & $(166)$ \\
\hline FZD6 & WNT receptor & $\begin{array}{l}\text { Nail dysplasia } \\
\text { Neural tube defects }\end{array}$ & & $\begin{array}{l}(167) \\
(115)\end{array}$ \\
\hline LRP5 & Canonical WNT receptor & $\begin{array}{l}\text { Exudative vitreoretinopathy } \\
\text { Osteoporosis-pseudoglioma syndrome } \\
\text { High-bone-mass diseases }\end{array}$ & & $\begin{array}{l}(91) \\
(74) \\
(71)\end{array}$ \\
\hline LRP6 & Canonical WNT receptor & $\begin{array}{l}\text { Osteoporosis and early-onset coronary artery disease } \\
\text { Neural tube defects } \\
\text { Selective tooth agenesis } 7\end{array}$ & & $\begin{array}{l}(75) \\
(115) \\
(163)\end{array}$ \\
\hline$N D P$ & FZD4 ligand & Exudative vitreoretinopathy & & $(91)$ \\
\hline PORCN & WNT palmitoleoylation & Focal dermal hypoplasia & & $(165)$ \\
\hline PRICKLE1 & Core PCP component & $\begin{array}{l}\text { Epilepsy } \\
\text { Neural tube defects }\end{array}$ & & $\begin{array}{l}(117) \\
(115)\end{array}$ \\
\hline PRICKLE2 & Core PCP component & $\begin{array}{l}\text { Autism } \\
\text { Epilepsy }\end{array}$ & & $\begin{array}{l}(119) \\
(118)\end{array}$ \\
\hline$R N F 43$ & FZD ubiquitination & Hereditary colorectal cancer & Cancer & $(29,31)$ \\
\hline$R O R 2$ & Non-canonical WNT receptor & $\begin{array}{l}\text { Brachydactyly type B1 } \\
\text { Robinow syndrome }\end{array}$ & & $\begin{array}{l}(128) \\
(127)\end{array}$ \\
\hline RSPO1 & RNF43/ZNRF3 antagonist & $\begin{array}{l}\text { Palmoplantar hyperkeratosis with skin squamous } \\
\text { cell carcinoma and sex reversal }\end{array}$ & & $(168)$ \\
\hline $\mathrm{RSPO} 2$ & RNF43/ZNRF3 antagonist & & Cancer & $(32)$ \\
\hline $\mathrm{RSPO3}$ & RNF43/ZNRF3 antagonist & & Cancer & $(32)$ \\
\hline $\mathrm{RSPO4}$ & RNF43/ZNRF3 antagonist & Congenital anonychia & & $(169)$ \\
\hline SFRP4 & WNT antagonist & Pyle disease & & (76) \\
\hline SOST & WNT-LRP5/6 antagonist & $\begin{array}{l}\text { Craniodiaphyseal dysplasia } \\
\text { Sclerosteosis } \\
\text { van Buchem disease }\end{array}$ & & $\begin{array}{l}(68) \\
(69) \\
(70)\end{array}$ \\
\hline VANGL1 & Core PCP component & Neural tube defects & & $(115)$ \\
\hline VANGL2 & Core PCP component & Neural tube defects & & $(115)$ \\
\hline$W N T 1$ & WNT ligand & $\begin{array}{l}\text { Osteogenesis imperfecta } \\
\text { Osteoporosis }\end{array}$ & & $\begin{array}{l}(73) \\
(73)\end{array}$ \\
\hline WNT3 & WNT ligand & Tetra-amelia syndrome & & $(155)$ \\
\hline WNT4 & WNT ligand & $\begin{array}{l}\text { Mullerian aplasia and hyperandrogenism } \\
\text { SERKAL syndrome }\end{array}$ & & $\begin{array}{l}(157) \\
(158)\end{array}$ \\
\hline WNT5A & WNT ligand & Robinow syndrome & & $(126)$ \\
\hline$W N T 7 A$ & WNT ligand & Fuhrmann syndrome & & $(156)$ \\
\hline WNT10A & WNT ligand & $\begin{array}{l}\text { Odonto-onycho-dermal dysplasia } \\
\text { Selective tooth agenesis } 4\end{array}$ & & $\begin{array}{l}(160) \\
(161)\end{array}$ \\
\hline$W N T 10 B$ & WNT ligand & Selective tooth agenesis 8 & & $(162)$ \\
\hline
\end{tabular}

the LRP6 gene (R611C) was found in patients with familial osteoporosis and early-onset coronary artery disease (75).
Heterozygous loss-of-function WNT1 mutation (C218G) occurs in patients with early-onset osteoporosis, and homo- 
zygous loss-of-function WNT1 mutation (S295X) occurs in patients with osteogenesis imperfecta (73). By contrast, homozygous loss-of-function SFRP4 mutations (V161fs, D167fs and R232X) give rise to Pyle disease, which is characterized by limb malformation, cortical-bone thinning and fracture, through enhanced non-canonical WNT5A signaling and osteoclastogenesis (76). In addition to the rare mutations mentioned above, BMD-associated single nucleotide polymorphisms (SNPs) in the CTNNB1, LRP5, SOST, WNT4 and WNT16 loci are also associated with slightly increased fracture risk (77). As rare mutations and common variations in the canonical WNT/ $\beta$-catenin signaling molecules are involved in the pathogenesis of osteoporosis, pro-WNT/ $\beta$-catenin signaling therapy is a rational option for the treatment of patients with osteoporosis.

\section{Vascular diseases}

Vascular development and homeostasis are coordinated by a network of VEGF, FGF, Notch, angiopoietin (ANGPT), WNT and other signaling cascades $(78,79)$. Endothelial cells are involved in the maintenance of blood and lymphatic vessels as well as the support of somatic stem cells, such as gastric stem cells, hematopoietic stem cells, liver stem cells, mesenchymal stem cells and neural stem cells $(80,81)$. VEGF signaling through VEGFR2 and FGF2 signaling through FGFR1/2 directly promote proliferation and migration of endothelial tip cells during angiogenic sprouting (82-84), and then, DLL and JAG signaling through Notch directly promote stabilization and elongation of endothelial stalk cells (85-87). ANGPT1 signaling through TIE2 in endothelial cells promotes vascular maturation and stability, whereas ANGPT2 signaling through TIE2 promotes vascular de-stabilization through ANGPT1 signaling inhibition (88). Aberrant canonical WNT/ $\beta$-catenin signaling activation in cancer cells induces VEGF upregulation (89), which leads to unstable and leaky tumor angiogenesis. By contrast, non-canonical Wnt5a/PCP signaling downregulates Cskn1 and Bax to promote endothelial proliferation and survival, respectively, and upregulates Tie2 to promote vascular maturation and stability (90). Canonical and noncanonical WNT signaling cascades are directly or indirectly involved in vascular pathophysiology.

Familial exudative vitreoretinopathy is a hereditary disorder that is characterized by partial vascular agenesis, neovascularization and exudation in the retina and susceptibility to blindness owing to retinal detachment (91). We cloned and characterized the human FZD4 gene in 1999 (92), and since then germline mutations in the FZD4 gene (such as $\mathrm{C} 45 \mathrm{Y}$, Y58C, W226X and W496X) have been reported in patients with exudative vitreoretinopathy (93-95) (Fig. 2). C45Y and Y58C FZD4 are missense mutations in the Frizzled-like domain that abolish NDP binding to FZD4, and W226X and W496X FZD4 are loss-of-function truncation mutations. NDP and LRP5 mutations have also been reported in patients with exudative vitreoretinopathy $(96,97)$. Loss-of-function LRP5 mutations occur in patients with osteoporosis-pseudoglioma syndrome and present with similar eye phenotypes (74), and a loss-of-function CTNNB1 mutation occurs in a patient with intellectual disability syndrome complicated with exudative vitreoretinopathy (51) as mentioned above. NDP is a secreted protein that binds to the extracellular Frizzled-like domain of FZD4 and activates the $\beta$-catenin signaling cascade through FZD4 and LRP5 receptors similar to canonical WNT ligands. Loss-of-function mutations in the NDP, FZD4, LRP5 and $C T N N B 1$ genes in patients with exudative vitreoretinopathy indicate involvement of the $\mathrm{NDP} / \beta$-catenin signaling defect in the pathogenesis of exudative vitreoretinopathy.

$\mathrm{Ndp}$ and $\mathrm{Wnt} 7 \mathrm{a} / \mathrm{b}$ are required for vascular development in the mouse retina and central nervous system, respectively $(97,98)$, and lithium chloride treatment that stabilizes $\beta$-catenin through GSK3 inhibition upregulates the Vegf level to ameliorate retinal vascular phenotypes in an Lrp5 knockout mouse model of familial exudative vitreoretinopathy (99). By contrast, Fzd4 signaling is required for retinal vascular stabilization and maturation (100), and WNT5A induces dissociation of Ga12/13 from FZD4 to promote p115RhoGEFmediated activation of the RHO signaling cascade in endothelial cells (101). As canonical WNT or NDP signaling to the $\beta$-catenin cascade can promote angiogenic sprouting indirectly through transcriptional upregulation of VEGF and FGF family ligands and non-canonical WNT signaling through FZD4 can promote retinal vascular stability and maturation, fine-tuning of the canonical and non-canonical WNT signaling cascade may be necessary for the treatment of patients with familial exudative vitreoretinopathy.

\section{Human diseases related to core PCP components}

PCP is defined as cellular polarity within the epithelial plane perpendicular to the cellular apico-basal axis (7). The Drosophila PCP pathway coordinates orientation of sensory bristles and hairs and the rotation pattern of ommatidia $(102,103)$, whereas the vertebrate PCP pathway regulates orientation of sensory hair cells in the inner ear, collective cell movements during embryogenesis (convergent extension movements during gastrulation and neural tube closure during neurulation) (104-107), directional movements of neural crest cells and tumor invasion (108-111). The PCP pathway is categorized as the Frizzled-Flamingo-dependent core PCP branch and Fat-Dachsous-dependent alternative or parallel PCP branch $(112,113)$.

Flamingo (Drosophila ortholog of human CELSR1, CELSR2 and CELSR3), Frizzled (including FZD3, FZD6 and FZD7), Dishevelled (DVL1, DVL2 and DVL3), Prickle (PRICKLE1 and PRICKLE2) and Van Gogh/Vang (VANGL1 and VANGL2) are core PCP components that constitute the Flamingo-mediated interaction of the FlamingoFrizzled-Dishevelled and Flamingo-Vang-Prickle complexes on the opposite sides of neighboring cells. The mammalian core PCP pathway overlaps with non-canonical WNT signaling through FZDs and DVLs to the Rac-JNK and RhoA-ROCK signaling cascades (Fig. 1). We entered the PCP research field through molecular cloning and characterization of novel human PCP genes, such as FZD3, FZD6, FZD7 and VANGL1, from 1998 to 2002 as fruits of the human WNTome project, and identification and characterization of PRICKLE1 and PRICKLE2 in 2003 as fruits of the Post-WNTome project (114). Dr Kibar's group opened up a new avenue for PCP genetics related to neural tube defects, and since then germline or de novo alterations in the core PCP components 
have been reported in human diseases, such as neural tube defects $(115,116)$, epilepsy $(117,118)$, autism $(118,119)$ and Robinow syndrome (120).

Neural tube defects, including anencephaly, craniorachischisis and myelomeningocele (open spina bifida), are the second most common birth defects in humans, and they occur in $\sim 1 / 1,000$ established pregnancies (121). As the neural tube is generated through orchestrated extension, upward bending and fusion of the neural plate during embryogenesis, failure of the collective movement of neural crest precursors results in neural tube defects (122). Environmental factors, such as teratogenic chemicals, and no less than 200 genetic factors are involved in the susceptibility to neural tube defects (123). Mutations in the WNT signaling related genes, such as CELSR1, DVL2, FZD6, LRP6, PRICKLE1, VANGL1 and $V A N G L 2$, occur in patients with neural tube defects (115). CELSR1, DVL2, FZD6, PRICKLE1, VANGL1 and VANGL2 are core PCP components that are involved in non-canonical WNT signaling cascades, whereas LRP6 is a canonical WNT receptor (Table I). LRP6 mutants (Y306H, Y373C and V1386L) repress Wnt3a-induced TCF/LEF-dependent transcription but potentiate Wnt5a-induced JNK-dependent transcription (116). In addition, a patient with intellectual disability syndrome caused by a loss-of-function CTNNB1 mutation presented with exudative vitreoretinopathy and neural tube defect as mentioned above (51). Mutations in the core PCP signaling molecules, as well as loss-of-function mutations in the canonical $\mathrm{WNT} / \beta$-catenin signaling molecules, give rise to neural tube defects.

The PRICKLE1 and PRICKLE2 genes are also mutated in patients with epilepsy and autism. Epilepsy is characterized by recurrent seizures, whereas autism is characterized by deficits in social interactions, communication and flexible behavior. Homozygous PRICKLE1 mutation (R104Q) occurs in familial cases of progressive myoclonus epilepsy with early-onset ataxia (117). Heterozygous PRICKLE1 mutations (R104Q, R144H and Y472H) and a PRICKLE2 mutation (R148H) occur in sporadic cases of progressive myoclonus epilepsy (118), whereas heterozygous PRICKLE2 mutations (E8Q and V153I) occur in autistic patients (119). Deletion of the PRICKLE2 gene is detected in patients with 3p14 microdeletion syndrome, one type of which is characterized by autism, epilepsy and developmental delay and another type of which is characterized by autism, intellectual disability and language disorder $(118,124)$. By contrast, loss-of-function mutation of the CTNNB1 gene is reported in a patient with autism, neural tube defect, intellectual disability and exudative vitreoretinopathy as mentioned above (51). As the development and maintenance of neural tissues are orchestrated by the spatiotemporal finetuning of the canonical and non-canonical WNT signaling cascades, genetic alterations in WNT signaling molecules cause overlapping neuropsychiatric disorders, such as autism, epilepsy and intellectual disability.

Robinow syndrome is a hereditary disorder that presents with common features, such as brachydactyly, frontal bossing, genital hypoplasia, hemivertebra, hypertelorism and mesomelic limb shortening (125). In addition to DVL1 and DVL3 mutations in patients with the autosomal dominant form of Robinow syndrome (120), WNT5A and ROR2 mutations occur in patients with autosomal dominant and autosomal recessive forms of Robinow syndrome, respectively $(126,127)$. By contrast, autosomal dominant ROR2 mutations occur in patients with brachydactyly type B1 (128). As WNT5A signaling through the ROR2 receptor activates DVL1/3-mediated RHO-ROCK and RAC1-JNK signaling cascades to regulate cell polarity and directional migration (129-132), loss-of-function mutations in the WNT5A, ROR2, DVL1 and DVL3 genes give rise to Robinow syndrome through impaired non-canonical WNT signaling (Fig. 2). However, osteosclerotic phenotypes in a subset of patients with Robinow syndrome (133) suggest reciprocal WNT/ $\beta$-catenin signaling activation in the bone, and Robinow syndrome-like phenotypes in mice with null and hypomorphic Prickle1 alleles (134) suggest the involvement of core PCP components other than DVLs in Robinow syndrome. Signaling mechanisms and Robinow syndrome genes should be further investigated.

WNT/PCP or WNT5A/ROR/Frizzled signaling promotes invasion, survival and therapeutic resistance of human cancers (135-141), although WNT5A or non-canonical WNT/Ca ${ }^{2+}$ signaling is context-dependently involved in tumor suppression (142-144). ROR1 is preferentially upregulated in B-cell leukemia, such as chronic lymphocytic leukemia (CLL) $(145)$ and $t(1 ; 19)$ acute lymphoblastic leukemia (ALL) (146). WNT5A-dependent oligomerization of ROR1 and ROR2 on CLL cells induces recruitment of the guanine exchange factors ARHGEF1, ARHGEF2 and ARHGEF6 and subsequent activation of RhoA and Rac1 to promote chemotaxis and proliferation, respectively (147). ROR1 is also upregulated in breast cancer, gastric cancer and lung cancer, and ROR1 phosphorylation by MET and SRC promote tumor proliferation and invasion (148-150). ROR1 interacts with TCL1A (TCL1) to activate AKT in a mouse model of CLL (151); ROR1 interacts with HER3 and LLGL2 in breast cancer cells to inhibit STK4 (MST1) through K59 methylation, which leads to transcriptional upregulation of YAP/TAZ-target genes (150); and ROR1 interacts with caveolae components in lung cancer cells to promote survival and resistance to EGFR inhibitors through MET- or IGF1R-dependent PI3K-AKT signaling activation (152). ROR1 upregulation in B-cell leukemias and solid tumors promote malignant phenotypes through ROR1 phosphorylation and activation of WNT/PCP and WNT/RTK signaling cascades (Fig. 4). By contrast, ROR2 is upregulated in invasive melanoma (153), and WNT5A/ROR2 signaling induces recruitment and activation of SRC to promote metastasis (154). WNT5A induces de-palmitoylation of MCAM adhesion molecules and subsequently polarizes localization of MCAM and CD44 to promote directional movement and invasion of melanoma cells (110). These facts clearly indicate that the WNT/PCP and WNT/RTK signaling cascades, as well as $\mathrm{WNT} / \beta$-catenin signaling cascade, drive human carcinogenesis (Fig. 4).

\section{Other genetic diseases}

WNT3 and WNT7A mutations are reported in patients with tetra-amelia syndrome and Fuhrmann syndrome, respectively $(155,156)$ which are characterized by congenital limb malformations. Heterozygous E216G WNT4 mutation causes mullerian aplasia and hyperandrogenism (157) whereas homozygous A114V WNT4 mutation causes SERKAL syndrome 
presenting female-to-male sex reversal and dysgenesis of kidneys, adrenal glands and lungs (158). We cloned and characterized human WNT6 and WNT10A in 2001 (159), and then, another group found a homozygous WNT10A E233X mutation in patients with odonto-onycho-dermal dysplasia characterized by severe hypodontia, onychodysplasia and keratoderma in 2007 (160). WNT10A, WNT1OB and LRP6 mutations occur in patients with selective tooth agenesis (161-163). By contrast, as porcupine (PORCN) is an O-acyltransferase that is involved in palmitoleoylation and subsequent secretion of WNT ligands (164), loss-of-function PORCN mutations lead to focal dermal hypoplasia characterized by patchy hypoplastic skin and other malformations (165).

In addition to FZD4 and FZD6 mutations in patients with exudative vitreoretinopathy (91) and neural tube defects (115), respectively, FZD5 mutations in patients with ocular coloboma (166) and FZD6 mutations in patients with nail dysplasia (167) have been reported. Loss-of-function RSPO1 mutations cause palmoplantar hyperkeratosis with skin squamous cell carcinoma and sex reversal (168), whereas RSPO4 missense mutations occur in patients with congenital anonychia (169).

Heterozygous Ser1591fs mutation in the DAPLE $(C C D C 88 C)$ gene has been reported in a patient with hydrocephalus (170). Wild-type DAPLE protein, containing the FZD-binding and G $\alpha$-binding/activation motifs in its C-terminal region, assembles FZD7 receptor and Gai protein to transduce non-canonical WNT5A/Rac1 and PI3K-AKT signaling cascades and inhibit the canonical WNT/ $\beta$-catenin signaling cascade (171), although the FZD7 receptor is involved in canonical WNT/ $\beta$-catenin signaling activation in intestinal stem cells (41). As the Ser1591fs DAPLE mutant in a hydrocephalus patient is resistant to nonsense-mediated mRNA decay (170) and lacks the FZD-binding and G $\alpha$-binding/ activation motifs, the truncating DAPLE mutation is predicted to impair non-canonical WNT/Rac1 and PI3K-AKT signaling cascades.

\section{Therapeutics targeting WNT signaling cascades}

Development of therapeutics that inhibit the WNT/ $\beta$-catenin signaling cascade is a topic of great interest in the field of clinical oncology and medicinal chemistry (172-175). By contrast, as aberrant activation and inhibition of WNT signaling cascades are involved in the pathogenesis of cancer and non-cancerous diseases (Table I), therapeutics that inhibit or potentiate canonical or non-canonical WNT signaling cascades are necessary for the future implementation of genome-based medicine for human diseases. WNT-targeted therapy will be discussed in this section with emphases on PORCN, RSPO3, WNT ligands, FZD receptors, ROR1 receptor, tankyrase and $\beta$-catenin as targets for anti-WNT signaling therapy (Table II) and DKK1, SOST and GSK $3 \beta$ as targets for pro-WNT signaling therapy (Table III).

PORCN is an endogenous WNT palmitoleoylase that promotes secretion of WNT family proteins and their interaction with FZD receptors (164), whereas NOTUM is an endogenous WNT de-palmitoleoylase that represses WNT-FZD interaction (176). Small-molecule inhibitors for PORCN and NOTUM are applicable to anti- and pro-WNT signaling thera- pies, respectively. ETC-159 (ETC-1922159) (177), IWP-2 (178), LGK974 (WNT974) (179) and WNT-C59 (180) are representative PORCN inhibitors that attenuate WNT signaling for in vivo treatment of colorectal cancer with $R S P O$ translocations and pancreatic cancer with RNF43 mutations (181-183) (Fig. 4) as well as non-cancerous diseases, such as cardiac fibrosis (184) and kidney fibrosis (185). By contrast, OMP-131R10 is an anti$\mathrm{RSPO} 3 \mathrm{mAb}$ that neutralizes RSPO3 to attenuate canonical WNT signaling through ubiquitylation-mediated FZD degradation (186). OMP-131R10 inhibits tumor growth in patient-derived xenograft models of colorectal cancers with $R S P O 3$ fusion or non-small cell lung cancers and ovarian cancers with RSPO3 upregulation (Fig. 4).ETC-159,LGK974 and OMP-131R10 are in clinical trials for the treatment of cancer patients (ClinicalTrials. gov; https://clinical-trials.gov) (Table II).

Between 1996 and 2002, we cloned and characterized human WNT2B, WNT3A, WNT5B, WNT6, WNT7B, WNT8A, WNT9A (WNT14), WNT9B (WNT14B), WNT10A, FZD1, FZD3, FZD4, FZD5, FZD6, FZD7, FZD8 and FZD10 as the major products of the human WNTome project $(1,2$ and references therein). Some of these WNTs and FZDs are potential targets for cancer therapy (Fig. 4). For example, as WNT2B is upregulated in diffuse-type gastric cancer, pancreatic cancer and nasopharyngeal carcinoma and involved in EMT, invasion and metastasis (187-190), WNT2B shRNAs have been used to inhibit tumorigenesis in mouse model experiments $(191,192)$. FZD6 upregulation in colorectal cancer, neuroblastoma and triple-negative breast cancer is involved in stem-like features, EMT and drug resistance (193-196). Based on FZD5 upregulation in solid tumors, including $R N F 43$-mutated pancreatic cancer $(197,198), F Z D 7$ upregulation in breast cancer, colorectal cancer, glioma and hepatocellular carcinoma (199-203) and FZD10 upregulation in breast cancer, colorectal cancer and synovial sarcoma (204-207), anti-FZD5 IgG, anti-FZD7 $\mathrm{mAb}$ and anti-FZD10 mAbs have been developed for cancer therapy. Vantictumab (OMP-18R5), initially isolated as an FZD7-binding antibody, is a broad-spectrum anti-FZD $\mathrm{mAb}$ that reacts with FZD1, FZD2, FZD5, FZD7 and FZD8 (208), which all belong to the FZD1/2/7 or FZD5/8 subfamily among the FZD family (204). OTSA101-DPTA-90Y is a ${ }^{90} \mathrm{Y}$-labeled anti-FZD10 mAb (209). By contrast, ipafricept (OMP-54F28) is a fusion protein that consists of the cysteine-rich domain of FZD8 and the Fc domain of immunoglobulin, and it functions as a trap for FZD8-binding WNT proteins (210). Vantictumab and OMP-54F28 are in clinical trials for the treatment of cancer patients (Table II). As the FZD7 receptor on intestinal stem cells, endothelial cells and solid tumors is involved in WNT signaling to the $\beta$-catenin, RhoA, Racl, PI3K and $\mathrm{Ca}^{2+}$ cascades $(41,171,211,212)$, FZD7 blockade gives rise to various effects in a cell context-dependent manner. The effectiveness and adverse effects of anti-FZD mAb drugs may be determined by the selectivity of mAbs and the context-dependent functions of targeted FZDs.

ROR1 is a rational target of cancer therapeutics as ROR1 is upregulated in subsets of B-cell leukemia, breast cancer, gastric cancer and lung cancer but undetectable in most adult tissues except immature B-cells (Fig. 4). In addition, ROR1 is involved in tumor proliferation, invasion and therapeutic resistance as mentioned above (145-152). ROR1, ROR2, NTRK1, NTRK2, NTRK3, MUSK, DDR1 and DDR2 
Table II. Anti-WNT signaling therapeutics.

\begin{tabular}{|c|c|c|c|c|c|}
\hline Target & Mechanism of action & Drug & Stage of drug development & Disease & (Refs.) \\
\hline WNT & PORCN inhibitor & $\begin{array}{l}\text { ETC-159 } \\
\text { IWP-2 } \\
\text { LGK974 } \\
\text { WNT-C59 }\end{array}$ & $\begin{array}{l}\text { Phase I } \\
\text { Preclinical } \\
\text { Phase I } \\
\text { Preclinical } \\
\text { Preclinical } \\
\text { Preclinical }\end{array}$ & $\begin{array}{l}\text { Cancer } \\
\text { Cancer } \\
\text { Cancer } \\
\text { Cancer } \\
\text { Cardiac fibrosis } \\
\text { Kidney fibrosis }\end{array}$ & $\begin{array}{l}(177) \\
(178) \\
(179) \\
(180) \\
(184) \\
(185)\end{array}$ \\
\hline WNT & FZD8-binding WNT trap & Ipafricept & Phase I & Cancer & $(210)$ \\
\hline RSPO3 & Anti-RSPO3 mAb & OMP-131R10 & Phase I & Cancer & $(186)$ \\
\hline FZDs & Anti-FZD1/2/5/7/8 mAb & Vantictumab & Phase I & Cancer & $(208)$ \\
\hline FZD5 & Anti-FZD5 mAb & IgG-2919 & Preclinical & Cancer & $(198)$ \\
\hline FZD10 & Anti-FZD10 mAb & OTSA101 & Phase I (terminated) & Cancer & $(209)$ \\
\hline ROR1 & $\begin{array}{l}\text { ROR1 inhibitor } \\
\text { Anti-ROR1 mAb } \\
\text { Anti-ROR1 } x \text { anti-CD3 } \\
\text { bispecific mAb } \\
\text { ROR1 CAR-T cells }\end{array}$ & $\begin{array}{l}\text { KAN } 0439834 \\
\text { Cirmtuzumab } \\
\text { ROR1-CD3-DART } \\
\text { APVO425 } \\
\text { ROR1R-CAR-T }\end{array}$ & $\begin{array}{l}\text { Preclinical } \\
\text { Phase I } \\
\text { Preclinical } \\
\text { Preclinical } \\
\text { Preclinical }\end{array}$ & $\begin{array}{l}\text { Cancer } \\
\text { Cancer } \\
\text { Cancer } \\
\text { Cancer } \\
\text { Cancer }\end{array}$ & $\begin{array}{l}(216) \\
(147) \\
(218) \\
(219) \\
(220)\end{array}$ \\
\hline AXIN & Tankyrase inhibitor & $\begin{array}{l}\text { AZ1366 } \\
\text { G007-LK } \\
\text { NVP-TNKS656 } \\
\text { XAV939 }\end{array}$ & $\begin{array}{l}\text { Preclinical } \\
\text { Preclinical } \\
\text { Preclinical } \\
\text { Preclinical } \\
\text { Preclinical }\end{array}$ & $\begin{array}{l}\text { Cancer } \\
\text { Cancer } \\
\text { Cancer } \\
\text { Cancer } \\
\text { Neuropathic pain }\end{array}$ & $\begin{array}{l}(239) \\
(240) \\
(241) \\
(243) \\
(245)\end{array}$ \\
\hline$\beta$-catenin & $\begin{array}{l}\text { Blockade of } \beta \text {-catenin } \\
\text { protein-protein-interaction }\end{array}$ & $\begin{array}{l}\text { LF3 } \\
\text { MSAB } \\
\text { PKF115-584 } \\
\text { PRI-724 } \\
\text { SAH-BCL9 }\end{array}$ & $\begin{array}{l}\text { Preclinical } \\
\text { Preclinical } \\
\text { Preclinical } \\
\text { Preclinical } \\
\text { Preclinical } \\
\text { Preclinical } \\
\text { Preclinical } \\
\text { Preclinical } \\
\text { Preclinical } \\
\text { Phase II } \\
\text { Preclinical }\end{array}$ & $\begin{array}{l}\text { Cancer } \\
\text { Cancer } \\
\text { Cancer } \\
\text { Cancer } \\
\text { Pulmonary fibrosis } \\
\text { CKD } \\
\text { Cancer } \\
\text { Cancer } \\
\text { Cancer } \\
\text { Cancer } \\
\text { Cancer }\end{array}$ & $\begin{array}{l}(252) \\
(253) \\
(254) \\
(255) \\
(261) \\
(262) \\
(256) \\
(257) \\
(258) \\
(259) \\
(260)\end{array}$ \\
\hline
\end{tabular}

CKD, chronic kidney disease; OTSA101, OTSA101-DPTA-90Y; PORCN, porcupine.

constitute the ROR/NTRK subfamily among the RTKs, whereas small-molecule inhibitors and mAbs are established approaches to target RTKs $(213,214)$. ROR 1 is predicted to be a pseudokinase that lacks intrinsic tyrosine kinase activity (215), but ROR1 is phosphorylated by other tyrosine kinases, such as MET and SRC, and activates downstream signaling cascades $(148,149)$. KAN 0439834 is a smallmolecule ROR1 inhibitor that dephosphorylates ROR1 in B-cell leukemia, breast cancer and lung cancer and induces a cytotoxic effect on ROR1-expressing tumor cells (216). Cirmtuzumab (UC-961) is a humanized anti-ROR $1 \mathrm{mAb}$ that inhibits WNT5A-induced ROR1 signaling through ROR1 dephosphorylation and represses in vivo growth of ROR1-expressing CLL cells $(147,217)$. ROR1-CD3-DART and APVO425 (ES425) are bispecific antibodies consisting of anti-ROR1 and anti-CD3 mAbs that redirect cytotoxic T cells to ROR1-expressing tumor cells $(218,219)$. ROR1 CAR-T cells were also developed for cancer therapy, and the effectiveness and safety of ROR1 CAR-T cells have been demonstrated in rodent as well as non-human primate model experiments (220). Cirmtuzumab is in clinical trials for the treatment of cancer patients (Table II).

SOST and DKK1 are endogenous canonical WNT antagonists that induce direct inhibition of osteoblastogenesis as well as indirect promotion of osteoclastogenesis, and are involved in the pathogenesis of osteoporosis and cancer-associated osteolysis, respectively $(64,221,222)$. As SOST and DKK1 are rational targets of pro-WNT signaling therapy for human diseases, anti-SOST mAbs (romosozumab, blosozumab and BPS804) (223-225), anti-DKK1 mAbs (BHQ880, DKN-01 
Table III. Pro-WNT signaling therapeutics.

\begin{tabular}{|c|c|c|c|c|c|}
\hline Target & Mechanism of action & Drug & Stage of drug development & Disease & (Refs.) \\
\hline \multirow[t]{3}{*}{ DKK1 } & Anti-DKK1 mAb & BHQ880 & Phase II & Cancer & (226) \\
\hline & & DKN-01 & Phase I & Cancer & (227) \\
\hline & & PF-04840082 & Preclinical & Osteoporosis & (228) \\
\hline \multirow[t]{3}{*}{ SOST } & Anti-SOST mAb & Blosozumab & Phase II & Osteoporosis & (224) \\
\hline & & BPS804 & Phase II & Osteoporosis & (225) \\
\hline & & Romosozumab & Phase III & Osteoporosis & (223) \\
\hline \multirow{4}{*}{$\beta$-catenin } & GSK3 $\beta$ inhibitor or & $\mathrm{BIO}$ & Reagent (in vitro) & & (246) \\
\hline & GSK3 inhibitor & CHIR99021 & Reagent (in vitro) & & (247) \\
\hline & & LY2090314 & Reagent (in vitro) & & (248) \\
\hline & & TWS119 & Reagent (in vitro) & & (249) \\
\hline
\end{tabular}

DKK1, Dickkopf-related protein 1; GSK3 $\beta$, glycogen synthase kinase $3 \beta$.

and PF-04840082) (226-228) and a bispecific antibody against SOST and DKK1 (Hetero-DS) (229) have been developed. Romosozumab, blosozumab and BPS804 are in clinical trials for female postmenopausal patients with decreased BMD, whereas BHQ880 and DKN-01 are in clinical trials for patients with multiple myeloma and other solid tumors, such as cholangiocarcinoma, esophageal cancer and gastric cancer (Table III).

Tankyrases (TNKS1/PARP5A and TNKS2/PARP5B), PARP1, PARP2, TIPARP (PARP7) and other PARPs are ADP-ribosyl transferases belonging to the PARP family (230-232), and ADP-ribosyl transferase inhibitors, such as olaparib, have been developed for cancer therapy (233-235). Tankyrases promote degradation of AXIN1 and AXIN2 through poly-ADP-ribosylation, and tankyrase inhibitors induce AXIN stabilization for canonical WNT/ $\beta$-catenin signaling inhibition (236-238). AZ1366 (239), G007-LK (240), NVP-TNKS656 $(241,242)$ and XAV939 $(243,244)$ are investigational tankyrase inhibitors that can block canonical $\mathrm{WNT} / \beta$-catenin signaling in model animal experiments to repress tumorigenesis (239-244), control neuropathic pain (245) and promote cardiac reprogramming from cardiac fibroblasts (24). As tankyrase inhibitors induce a variety of effects, such as canonical WNT/ $\beta$-catenin signaling inhibition, YAP signaling inhibition, PI3K signaling inhibition and telomere shortening through defective poly-ADP-ribosylation of AXIN, AMOT, PTEN and TERF1, respectively (236-238), the tankyrase inhibitors mentioned above are not in clinical trials at present (Table II).

$\beta$-catenin is an effector of the WNT/ $\beta$-catenin signaling cascade (2-4), and stabilized nuclear $\beta$-catenin associates with BCL9, CBP, p300, EZH2 and SMARCA4 to activate transcription of TCF/LEF-target genes (Fig. 3). As $\beta$-catenin does not have intrinsic enzymatic activity, $\beta$-catenin inhibitors have been developed with a focus on its protein-protein interactions (175). BIO (246), CHIR99021 (247), LY2090314 (248) and TWS119 (249) are GSK3 $\beta$ or GSK3 inhibitors that can activate the WNT/ $\beta$-catenin signaling cascade (Table III). GSK3 $\beta$ inhibitors are applied as pro-WNT signaling reagents for cell processing in the field of regenerative medicine $(250,251)$; however, clinical application of GSK3 $\beta$ inhibitors as pro-WNT signaling therapeutics for patients with impaired WNT/ $\beta$-catenin signaling is too challenging. By contrast, BC2059 (252), CGP049090 (253), CWP232228 (254), ICG-001 (255), LF3 (256), MSAB (257), PKF115-584 (258), PRI-724 (259) and SAH-BCL9 (260) are $\beta$-catenin inhibitors that induce antitumor effects through repression of TCF/LEF-target genes, whereas some of these $\beta$-catenin inhibitors also show therapeutic effects in model animal experiments of non-cancerous diseases, such as pulmonary fibrosis and chronic kidney disease $(261,262)$. PRI-724 is in clinical trials for cancer patients (Table II).

Cancer cells interact with immune cells and stromal cells to regulate antitumor immunity, angiogenesis and metabolism in the tumor microenvironment $(78,213,263,264)$. WNT/ $\beta$ catenin signaling activation in cancer cells indirectly regulates immunity through transcriptional regulation of CCL4 chemokine or ULBP ligands for dendritic cells and natural killer cells, respectively $(265,266)$, whereas canonical or noncanonical WNT signaling activation in dendritic cells (267), macrophages (268), myeloid-derived suppressor cells (269) and $\mathrm{T}$ lymphocytes (270) directly regulates their functions and antitumor immunity. WNT/ $\beta$-catenin signaling activation in dendritic cells can enhance immune evasion through accumulation of regulatory $\mathrm{T}$ cells (271-273), and anti-WNT signaling therapy using a PORCN inhibitor, tankyrase inhibitor or $\beta$-catenin inhibitor may be applicable for the treatment of immune evasion (Fig. 5). By contrast, WNT/ $\beta$-catenin signaling inhibition in cancer cells or tumor microenvironment owing to DKK1 upregulation can also lead to immune evasion through the accumulation of myeloid-derived suppressor cells and clearance of natural killer and cytotoxic T cells $(266,269,274)$, and pro-WNT signaling therapy using an anti-DKK1 mAb may be applicable for the treatment of immune evasion in cancer patients with DKK1 upregulation (Fig. 5). As WNT signaling cascades in cancer cells, stromal cells and immune cells regulate immune tolerance and antitumor immunity in a cell context-dependent manner, comprehensive understanding of WNT-dependent dynamic immune regulation based on precise immune monitoring is necessary before prescription of anti- 


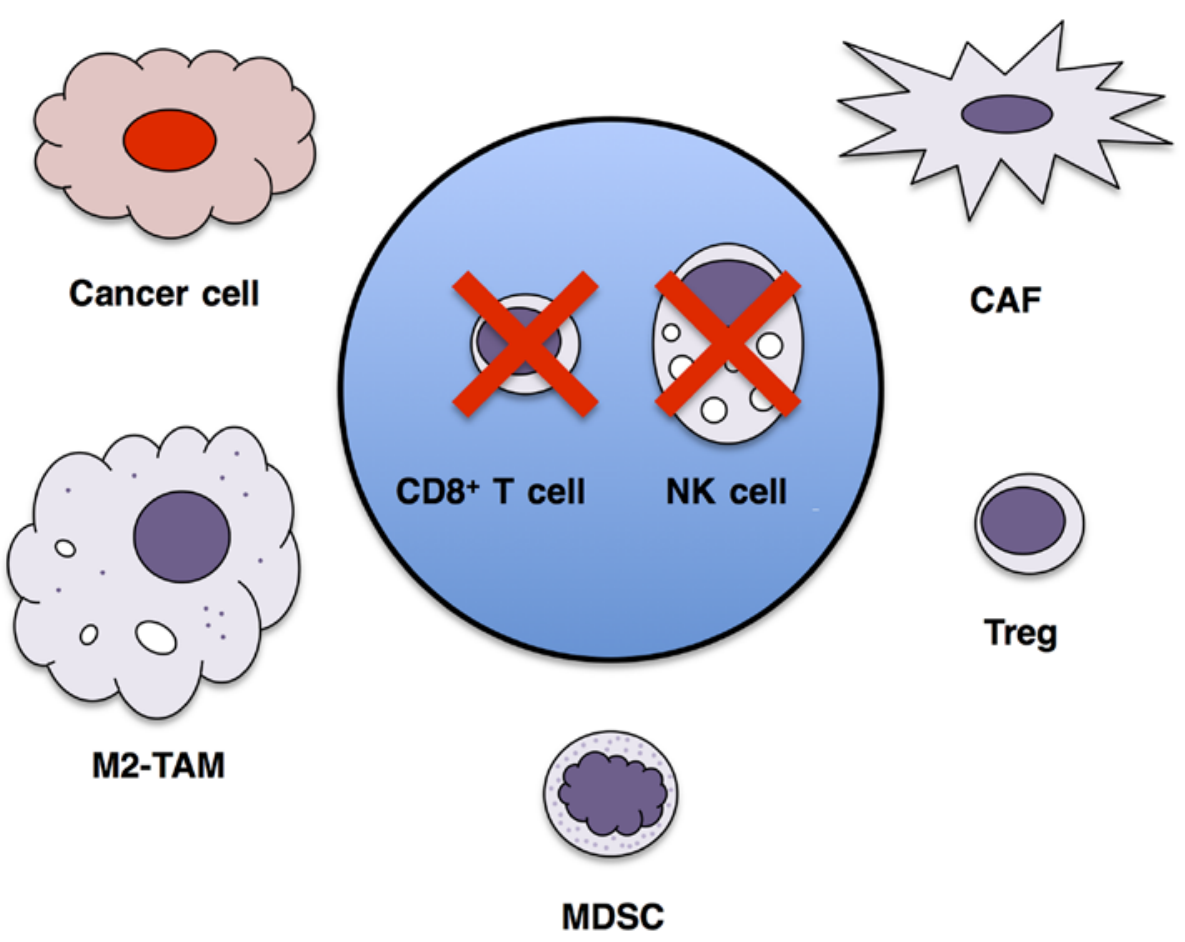

WNT/ $\beta$-catenin signaling activation in DCs

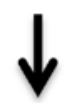

Immune evasion owing to Treg accumulation

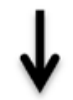

PORCN, tankyrase or $\beta$-catenin inhibitor (Preclinical study)

\begin{abstract}
DKK1-induced WNT/ $\beta$-catenin signaling inhibition or reciprocal non-canonical WNT signaling activation in cancer cells or tumor microenvironment
\end{abstract}
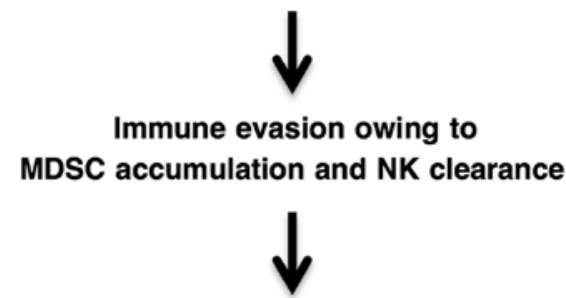

Anti-DKK1 monoclonal antibody

(Preclinical study)

Figure 5. Context-dependent WNT signaling and immune evasion. Cancer cells and CAFs dictate accumulation of M2-TAMs, MDSCs and regulatory T (Treg) cells in the tumor environment to give rise to immune evasion through clearance or functional inhibition of CD8 ${ }^{+}$effector T cells and NK cells. WNT/ $\beta$-catenin signaling activation in DCs can enhance immune evasion through Treg accumulation in the tumor microenvironment, whereas DKK1-induced WNT/ $\beta$-catenin signaling inhibition in cancer cells or the tumor microenvironment can also enhance immune evasion through MDSC accumulation and NK clearance. Anti-WNT signaling therapy using PORCN inhibitor, tankyrase inhibitor or $\beta$-catenin inhibitor may be applicable for the treatment of immune evasion induced by WNT/ $\beta$-catenin signaling activation. By contrast, pro-WNT signaling therapy using an anti-DKK1 monoclonal antibody may be applicable for the treatment of immune evasion associated with DKK1 upregulation. As WNT signaling cascades are involved in context-dependent immune evasion and antitumor immunity, precise immune monitoring and comprehensive understanding of WNT-dependent immune regulation are necessary to apply WNT-targeted therapy for cancer patients with immune evasion. CAFs, cancer-associated fibroblasts; M2-TAMs, M2-type tumor associated macrophages; NK, natural killer; DCs, dendritic cells; MDSCs, myeloid-derived suppressor cells; PORCN, porcupine; DKK1, Dickkopf-related protein 1.

or pro-WNT signaling therapeutics for cancer patients with immune evasion.

\section{Conclusion}

WNT signaling molecules are dysregulated in human diseases, such as cancer, bone diseases, cardiovascular diseases, neuropsychiatric diseases and other PCP-related diseases. Therapeutics targeting PORCN, RSPO3, FZD receptors, ROR1, $\beta$-catenin and DKK1 are in clinical trials for cancer patients, and SOST-targeting therapeutics are in clinical trials for osteoporotic patients. Fine-tuning of WNT-targeting therapeutics is necessary for the optimization of their clinical efficacy and safety, as WNT signals regulate a variety of pathophysiological conditions in a context-dependent manner. WNT-targeting therapeutics have also been applied as in vitro stem-cell processing reagents for regenerative medicine.

\section{Acknowledgements}

This study was financially supported in part by a Grant-in-Aid for the knowledge base project from M. Katoh's Fund. 


\section{References}

1. Katoh M: $W N T$ and $F G F$ gene clusters (Review). Int J Oncol 21: 1269-1273, 2002.

2. Katoh M and Katoh M: WNT signaling pathway and stem cell signaling network. Clin Cancer Res 13: 4042-4045, 2007.

3. Niehrs C: The complex world of WNT receptor signalling. Nat Rev Mol Cell Biol 13: 767-779, 2012.

4. Yang K, Wang X, Zhang H, Wang Z, Nan G, Li Y, Zhang F, Mohammed MK, Haydon RC, Luu HH, et al: The evolving roles of canonical WNT signaling in stem cells and tumorigenesis: Implications in targeted cancer therapies. Lab Invest 96: 116-136, 2016.

5. Acebron SP and Niehrs C: $\beta$-catenin-independent roles of Wnt/LRP6 signaling. Trends Cell Biol 26: 956-967, 2016.

6. Rada P, Rojo AI, Offergeld A, Feng GJ, Velasco-Martín JP, González-Sancho JM, Valverde ÁM, Dale T, Regadera J and Cuadrado A: WNT-3A regulates an Axin1/NRF2 complex that regulates antioxidant metabolism in hepatocytes. Antioxid Redox Signal 22: 555-571, 2015.

7. Katoh M: WNT/PCP signaling pathway and human cancer (Review). Oncol Rep 14: 1583-1588, 2005.

8. Zhang S, Chen L, Cui B, Chuang HY, Yu J, Wang-Rodriguez J, Tang L, Chen G, Basak GW and Kipps TJ: ROR1 is expressed in human breast cancer and associated with enhanced tumor-cell growth. PLoS One 7: e31127, 2012.

9. Zhuo W and Kang Y: Lnc-ing ROR1-HER3 and Hippo signalling in metastasis. Nat Cell Biol 19: 81-83, 2017.

10. Medema JP: Cancer stem cells: The challenges ahead. Nat Cell Biol 15: 338-344, 2013

11. Holland JD, Klaus A, Garratt AN and Birchmeier W: Wnt signaling in stem and cancer stem cells. Curr Opin Cell Biol 25: 254-264, 2013.

12. Lamb R, Bonuccelli G, Ozsvári $B$, Peiris-Pagès $M$, Fiorillo $M$, Smith DL, Bevilacqua G, Mazzanti CM, McDonnell LA, Naccarato AG, et al: Mitochondrial mass, a new metabolic biomarke for stem-like cancer cells: Understanding WNT/FGF-driven anabolic signaling. Oncotarget 6: 30453-30471, 2015.

13. Tam WL and Weinberg RA: The epigenetics of epithelialmesenchymal plasticity in cancer. Nat Med 19: 1438-1449, 2013.

14. Ranganathan P, Weaver KL and Capobianco AJ: Notch signalling in solid tumours: A little bit of everything but not all the time. Nat Rev Cancer 11: 338-351, 2011.

15. Gonzalez DM and Medici D: Signaling mechanisms of the epithelial-mesenchymal transition. Sci Signal 7: re8, 2014.

16. Katoh $\mathrm{M}$ and Nakagama H: FGF receptors: Cancer biology and therapeutics. Med Res Rev 34: 280-300, 2014.

17. Yu M, Ting DT, Stott SL, Wittner BS, Ozsolak F, Paul S, Ciciliano JC, Smas ME, Winokur D, Gilman AJ, et al: RNA sequencing of pancreatic circulating tumour cells implicates WNT signalling in metastasis. Nature 487: 510-513, 2012.

18. Bozdag S, Li A, Riddick G, Kotliarov Y, Baysan M, Iwamoto FM, Cam MC, Kotliarova S and Fine HA: Age-specific signatures of glioblastoma at the genomic, genetic, and epigenetic levels. PLoS One 8: e62982, 2013.

19. Miyamoto DT,Zheng Y,Wittner BS,Lee RJ,Zhu H,BroderickKT, Desai R, Fox DB, Brannigan BW, Trautwein J, et al: RNA-Seq of single prostate CTCs implicates noncanonical Wnt signaling in antiandrogen resistance. Science 349: 1351-1356, 2015.

20. Gu Z, Churchman M, Roberts K, Li Y, Liu Y, Harvey RC, McCastlain K, Reshmi SC, Payne-Turner D, Iacobucci I, et al: Genomic analyses identify recurrent MEF2D fusions in acute lymphoblastic leukaemia. Nat Commun 7: 13331, 2016.

21. Pettinato G, Ramanathan R, Fisher RA, Mangino MJ, Zhang N and Wen X: Scalable differentiation of human iPSCs in a multicellular spheroid-based 3D culture into hepatocyte-like cells through direct Wnt/ß-catenin pathway inhibition. Sci Rep 6: 32888, 2016.

22. Motono M, Ioroi Y, Ogura T and Takahashi J: WNT-C59, a small-molecule WNT inhibitor, efficiently induces anterior cortex that includes cortical motor neurons from human pluripotent stem cells. Stem Cells Transl Med 5: 552-560, 2016.

23. Matsuno K, Mae SI, Okada C, Nakamura M, Watanabe A, Toyoda T, Uchida E and Osafune K: Redefining definitive endoderm subtypes by robust induction of human induced pluripotent stem cells. Differentiation 92: 281-290, 2016.

24. Mohamed TM, Stone NR, Berry EC, Radzinsky E, Huang Y, Pratt K, Ang YS, Yu P, Wang H, Tang S, et al: Chemical enhancement of in vitro and in vivo direct cardiac reprogramming. Circulation 135: 978-995, 2017.
25. Tao L, Zhang J, Meraner P, Tovaglieri A, Wu X, Gerhard R, Zhang X, Stallcup WB, Miao J, He X, et al: Frizzled proteins are colonic epithelial receptors for $C$. difficile toxin B. Nature 538: 350-355, 2016.

26. Collery RF, Volberding PJ, Bostrom JR, Link BA and Besharse JC: Loss of zebrafish $m f r p$ causes nanophthalmia, hyperopia, and accumulation of subretinal macrophages. Invest Ophthalmol Vis Sci 57: 6805-6814, 2016.

27. Kinzler KW and Vogelstein B: Lessons from hereditary colorectal cancer. Cell 87: 159-170, 1996.

28. Lammi L, Arte S, Somer M, Jarvinen H, Lahermo P, Thesleff I, Pirinen $\mathrm{S}$ and Nieminen P: Mutations in AXIN2 cause familial tooth agenesis and predispose to colorectal cancer. Am J Hum Genet 74: 1043-1050, 2004.

29. Gala MK, Mizukami Y, Le LP, Moriichi K, Austin T, Yamamoto M, Lauwers GY, Bardeesy N and Chung DC: Germline mutations in oncogene-induced senescence pathways are associated with multiple sessile serrated adenomas. Gastroenterology 146: 520-529, 2014.

30. Muzny DM, Bainbridge MN, Chang K, Dinh HH, Drummond JA, Fowler G, Kovar CL, Lewis LR, Morgan MB, Newsham IF, et al; Cancer Genome Atlas Network: Comprehensive molecular characterization of human colon and rectal cancer. Nature 487: 330-337, 2012

31. Giannakis M, Mu XJ, Shukla SA, Qian ZR, Cohen O, Nishihara R, Bahl S, Cao Y, Amin-Mansour A, Yamauchi M, et al: Genomic correlates of immune-cell infiltrates in colorectal carcinoma. Cell Rep 15: 857-865, 2016.

32. Seshagiri S, Stawiski EW, Durinck S, Modrusan Z, Storm EE, Conboy CB, Chaudhuri S, Guan Y, Janakiraman V, Jaiswal BS, et al: Recurrent R-spondin fusions in colon cancer. Nature 488: 660-664, 2012.

33. Ciriello G, Gatza ML, Beck AH, Wilkerson MD, Rhie SK, Pastore A, Zhang H, McLellan M, Yau C, Kandoth C, et al; TCGA Research Network: Comprehensive molecular portraits of invasive lobular breast cancer. Cell 163: 506-519, 2015.

34. Bass AJ, Thorsson V, Shmulevich I, Reynolds SM, Miller M, Bernard B, Hinoue T, Laird PW, Curtis C, Shen H, et al; Cancer Genome Atlas Research Network: Comprehensive molecular characterization of gastric adenocarcinoma. Nature 513: 202-209, 2014.

35. Guichard C, Amaddeo G, Imbeaud S, Ladeiro Y, Pelletier L, Maad IB, Calderaro J, Bioulac-Sage P, Letexier M, Degos F, et al: Integrated analysis of somatic mutations and focal copy-number changes identifies key genes and pathways in hepatocellular carcinoma. Nat Genet 44: 694-698, 2012.

36. Campbell JD, Alexandrov A, Kim J, Wala J, Berger AH, Pedamallu CS, Shukla SA, Guo G, Brooks AN, Murray BA, et al; Cancer Genome Atlas Research Network: Distinct patterns of somatic genome alterations in lung adenocarcinomas and squamous cell carcinomas. Nat Genet 48: 607-616, 2016.

37. Bailey P, Chang DK, Nones K, Johns AL, Patch AM, Gingras MC, Miller DK, Christ AN, Bruxner TJ, Quinn MC, et al; Australian Pancreatic Cancer Genome Initiative: Genomic analyses identify molecular subtypes of pancreatic cancer. Nature 531: 47-52, 2016.

38. Robinson D, Van Allen EM, Wu YM, Schultz N, Lonigro RJ, Mosquera JM, Montgomery B, Taplin ME, Pritchard CC, Attard G, et al: Integrative clinical genomics of advanced prostate cancer. Cell 161: 1215-1228, 2015.

39. Kandoth C, Schultz N, Cherniack AD, Akbani R, Liu Y, Shen H, Robertson AG, Pashtan I, Shen R, Benz CC, et al; Cancer Genome Atlas Research Network: Integrated genomic characterization of endometrial carcinoma. Nature 497: 67-73, 2013.

40. Barker N: Adult intestinal stem cells: Critical drivers of epithelial homeostasis and regeneration. Nat Rev Mol Cell Biol 15: 19-33, 2014.

41. Flanagan DJ, Phesse TJ, Barker N, Schwab RH, Amin N, Malaterre J, Stange DE, Nowell CJ, Currie SA, Saw JT, et al: Frizzled7 functions as a Wnt receptor in intestinal epithelial Lgr5(+) stem cells. Stem Cell Reports 4: 759-767, 2015.

42. Jiang $X$ and Cong F: Novel regulation of Wnt signaling at the proximal membrane level. Trends Biochem Sci 41: 773-783, 2016.

43. Valenta T, Hausmann $G$ and Basler K: The many faces and functions of $\beta$-catenin. EMBO J 31: 2714-2736, 2012.

44. Katoh M: Mutation spectra of histone methyltransferases with canonical SET domains and EZH2-targeted therapy. Epigenomics 8: 285-305, 2016.

45. Wang Z, Liu P, Inuzuka H and Wei W: Roles of F-box proteins in cancer. Nat Rev Cancer 14: 233-247, 2014. 
46. Kajiguchi T, Katsumi A, Tanizaki R, Kiyoi $H$ and Naoe $T$ : Y654 of $\beta$-catenin is essential for FLT3/ITD-related tyrosine phosphorylation and nuclear localization of $\beta$-catenin. Eur $\mathbf{J}$ Haematol 88: 314-320, 2012.

47. Jin B, Ding K and Pan J: Ponatinib induces apoptosis in imatinibresistant human mast cells by dephosphorylating mutant D816V KIT and silencing $\beta$-catenin signaling. Mol Cancer Ther 13: 1217-1230, 2014.

48. Fernández-Sánchez ME, Barbier S, Whitehead J, Béalle G, Michel A, Latorre-Ossa H, Rey C, Fouassier L, Claperon A, Brullé L, et al: Mechanical induction of the tumorigenic $\beta$-catenin pathway by tumour growth pressure. Nature 523: 92-95, 2015.

49. van Veelen W, Le NH, Helvensteijn W, Blonden L, Theeuwes M, Bakker ER, Franken PF, van Gurp L, Meijlink F, van der Valk MA, et al: $\beta$-catenin tyrosine 654 phosphorylation increases $\mathrm{Wnt}$ signalling and intestinal tumorigenesis. Gut 60: 1204-1212, 2011.

50. Kuechler A, Willemsen MH, Albrecht B, Bacino CA, Bartholomew DW, van Bokhoven $\mathrm{H}$, van den Boogaard MJ, Bramswig N, Büttner C, Cremer K, et al: De novo mutations in $\beta$-catenin $(C T N N B 1)$ appear to be a frequent cause of intellectual disability: Expanding the mutational and clinical spectrum. Hum Genet 134: 97-109, 2015.

51. Dixon MW, Stem MS, Schuette JL, Keegan CE and Besirli CG: CTNNB1 mutation associated with familial exudative vitreoretinopathy (FEVR) phenotype. Ophthalmic Genet 37: 468-470, 2016.

52. Lui JH, Hansen DV and Kriegstein AR: Development and evolution of the human neocortex. Cell 146: 18-36, 2011.

53. Inestrosa NC and Arenas E: Emerging roles of Wnts in the adult nervous system. Nat Rev Neurosci 11: 77-86, 2010.

54. Bayod S, Felice P, Andrés P, Rosa P, Camins A, Pallàs M and Canudas AM: Downregulation of canonical Wnt signaling in hippocampus of SAMP8 mice. Neurobiol Aging 36: 720-729, 2015.

55. Wakabayashi T, Hidaka R, Fujimaki S, Asashima $M$ and Kuwabara T: Diabetes impairs Wnt3 protein-induced neurogenesis in olfactory bulbs via glutamate transporter 1 inhibition. J Biol Chem 291: 15196-15211, 2016.

56. Marzo A, Galli S, Lopes D, McLeod F, Podpolny M, Segovia-Roldan M, Ciani L, Purro S, Cacucci F, Gibb A, et al: Reversal of synapse degeneration by restoring Wnt signaling in the adult hippocampus. Curr Biol 26: 2551-2561, 2016.

57. Lu T, Aron L, Zullo J, Pan Y, Kim H, Chen Y, Yang TH, Kim HM, Drake D, Liu XS, et al: REST and stress resistance in ageing and Alzheimer's disease. Nature 507: 448-454, 2014

58. Dias C, Feng J, Sun H, Shao NY, Mazei-Robison MS, Damez-Werno D, Scobie K, Bagot R, LaBonté B, Ribeiro E, et al $\beta$-catenin mediates stress resilience through Dicer1/microRNA regulation. Nature 516: 51-55, 2014.

59. Madison JM, Zhou F, Nigam A, Hussain A, Barker DD Nehme R, van der Ven K, Hsu J, Wolf P, Fleishman M, et al: Characterization of bipolar disorder patient-specific induced pluripotent stem cells from a family reveals neurodevelopmental and mRNA expression abnormalities. Mol Psychiatry 20: 703-717, 2015.

60. Karantalis V and Hare JM: Use of mesenchymal stem cells for therapy of cardiac disease. Circ Res 116: 1413-1430, 2015

61. Atashi F, Modarressi A and Pepper MS: The role of reactive oxygen species in mesenchymal stem cell adipogenic and osteogenic differentiation: A review. Stem Cells Dev 24: 1150-1163, 2015.

62. Chen Y and Alman BA: Wnt pathway, an essential role in bone regeneration. J Cell Biochem 106: 353-362, 2009.

63. Zhang R, Oyajobi BO, Harris SE, Chen D, Tsao C, Deng HW and Zhao M: Wnt/ $\beta$-catenin signaling activates bone morphogenetic protein 2 expression in osteoblasts. Bone 52: 145-156, 2013.

64. Ke HZ, Richards WG, Li X and Ominsky MS: Sclerostin and Dickkopf-1 as therapeutic targets in bone diseases. Endocr Rev 33: 747-783, 2012

65. Boudin E, Fijalkowski I, Piters E and Van Hul W: The role of extracellular modulators of canonical Wnt signaling in bone metabolism and diseases. Semin Arthritis Rheum 43: 220-240, 2013.

66. Silva BC and Bilezikian JP: Parathyroid hormone: Anabolic and catabolic actions on the skeleton. Curr Opin Pharmacol 22: $41-50,2015$.

67. Maeda K, Kobayashi Y, Udagawa N, Uehara S, Ishihara A, Mizoguchi T, Kikuchi Y, Takada I, Kato S, Kani S, et al: Wnt5a-Ror2 signaling between osteoblast-lineage cells and osteoclast precursors enhances osteoclastogenesis. Nat Med 18: 405-412, 2012
68. Kim SJ, Bieganski T, Sohn YB, Kozlowski K, Semënov M, Okamoto N, Kim CH, Ko AR, Ahn GH, Choi YL, et al: Identification of signal peptide domain SOST mutations in autosomal dominant craniodiaphyseal dysplasia. Hum Genet 129: 497-502, 2011.

69. Brunkow ME, Gardner JC, Van Ness J, Paeper BW, Kovacevich BR, Proll S, Skonier JE, Zhao L, Sabo PJ, Fu Y, et al: Bone dysplasia sclerosteosis results from loss of the SOST gene product, a novel cystine knot-containing protein. Am J Hum Genet 68: 577-589, 2001.

70. Balemans W, Patel N, Ebeling M, Van Hul E, Wuyts W, Lacza C, Dioszegi M, Dikkers FG, Hildering P, Willems PJ, et al: Identification of a $52 \mathrm{~kb}$ deletion downstream of the SOST gene in patients with van Buchem disease. J Med Genet 39: 91-97, 2002.

71. Van Wesenbeeck L, Cleiren E, Gram J, Beals RK, Bénichou O, Scopelliti D, Key L, Renton T, Bartels C, Gong Y, et al: Six novel missense mutations in the LDL receptor-related protein 5 (LRP5) gene in different conditions with an increased bone density. Am J Hum Genet 72: 763-771, 2003.

72. Canalis E: Wnt signalling in osteoporosis: Mechanisms and novel therapeutic approaches. Nat Rev Endocrinol 9: 575-583, 2013.

73. Laine CM, Joeng KS, Campeau PM, Kiviranta R, Tarkkonen K, Grover M, Lu JT, Pekkinen M, Wessman M, Heino TJ, et al: WNT1 mutations in early-onset osteoporosis and osteogenesis imperfecta. N Engl J Med 368: 1809-1816, 2013.

74. Gong Y, Slee RB, Fukai N, Rawadi G, Roman-Roman S, Reginato AM, Wang H, Cundy T, Glorieux FH, Lev D, et al; Osteoporosis-Pseudoglioma Syndrome Collaborative Group: LDL receptor-related protein 5 (LRP5) affects bone accrual and eye development. Cell 107: 513-523, 2001.

75. Mani A, Radhakrishnan J, Wang H, Mani A, Mani MA, Nelson-Williams C, Carew KS, Mane S, Najmabadi H, Wu D, et al: LRP6 mutation in a family with early coronary disease and metabolic risk factors. Science 315: 1278-1282, 2007.

76. Simsek Kiper PO, Saito H, Gori F, Unger S, Hesse E, Yamana K, Kiviranta R, Solban N, Liu J, Brommage R, et al: Cortical-bone fragility: Insights from sFRP4 deficiency in Pyle's disease. N Engl J Med 374: 2553-2562, 2016.

77. Estrada K, Styrkarsdottir U, Evangelou E, Hsu YH, Duncan EL, Ntzani EE, Oei L, Albagha OM, Amin N, Kemp JP, et al: Genome-wide meta-analysis identifies 56 bone mineral density loci and reveals 14 loci associated with risk of fracture. Nat Genet 44: 491-501, 2012.

78. Carmeliet P and Jain RK: Molecular mechanisms and clinical applications of angiogenesis. Nature 473: 298-307, 2011.

79. Katoh M: Therapeutics targeting angiogenesis: Genetics and epigenetics, extracellular miRNAs and signaling networks (Review). Int J Mol Med 32: 763-767, 2013.

80. Hayakawa Y, Ariyama H, Stancikova J, Sakitani K, Asfaha S, Renz BW, Dubeykovskaya ZA, Shibata W, Wang H, Westphalen CB, et al: Mistl expressing gastric stem cells maintain the normal and neoplastic gastric epithelium and are supported by a perivascular stem cell niche. Cancer Cell 28: 800-814, 2015.

81. Rafii S, Butler JM and Ding BS: Angiocrine functions of organ-specific endothelial cells. Nature 529: 316-325, 2016.

82. Goel HL and Mercurio AM: VEGF targets the tumour cell. Nat Rev Cancer 13: 871-882, 2013.

83. Ferrara N and Adamis AP: Ten years of anti-vascular endothelial growth factor therapy. Nat Rev Drug Discov 15: 385-403, 2016.

84. Katoh M: Therapeutics targeting FGF signaling network in human diseases. Trends Pharmacol Sci 37: 1081-1096, 2016.

85. Zhou W, Wang G and Guo S: Regulation of angiogenesis via Notch signaling in breast cancer and cancer stem cells. Biochim Biophys Acta 1836: 304-320, 2013

86. Zhang P, Yan X, Chen Y, Yang Z and Han H: Notch signaling in blood vessels: From morphogenesis to homeostasis. Sci China Life Sci 57: 774-780, 2014.

87. Rostama B, Peterson SM, Vary CP and Liaw L: Notch signal integration in the vasculature during remodeling. Vascul Pharmacol 63: 97-104, 2014.

88. Hilbert $\mathrm{T}$ and Klaschik $\mathrm{S}$ : The angiopoietin/TIE receptor system: Focusing its role for ischemia-reperfusion injury. Cytokine Growth Factor Rev 26: 281-291, 2015.

89. Zhang X, Gaspard JP and Chung DC: Regulation of vascular endothelial growth factor by the Wnt and K-ras pathways in colonic neoplasia. Cancer Res 61: 6050-6054, 2001.

90. Korn C, Scholz B, Hu J, Srivastava K, Wojtarowicz J, Arnsperger T, Adams RH, Boutros M, Augustin HG and Augustin I: Endothelial cell-derived non-canonical Wnt ligands control vascular pruning in angiogenesis. Development 141: 1757-1766, 2014. 
91. Gilmour DF: Familial exudative vitreoretinopathy and related retinopathies. Eye (Lond) 29: 1-14, 2015.

92. Kirikoshi H, Sagara N, Koike J, Tanaka K, Sekihara H, Hirai M and Katoh M: Molecular cloning and characterization of human Frizzled-4 on chromosome 11q14-q21. Biochem Biophys Res Commun 264: 955-961, 1999.

93.Zhang K, Harada Y, Wei X, Shukla D, Rajendran A, Tawansy K, Bedell M, Lim S, Shaw PX, He X, et al: An essential role of the cysteine-rich domain of FZD4 in Norrin/Wnt signaling and familial exudative vitreoretinopathy. J Biol Chem 286: 10210-10215, 2011

94. Musada GR, Syed H, Jalali S, Chakrabarti S and Kaur I: Mutation spectrum of the FZD-4, TSPAN12 and ZNF408 genes in Indian FEVR patients. BMC Ophthalmol 16: 90, 2016.

95. Tang M, Ding X, Li J, Hu A, Yuan M, Yang Y, Zhan Z, Li Z and Lu L: Novel mutations in FZD4 and phenotype-genotype correlation in Chinese patients with familial exudative vitreoretinopathy. Mol Vis 22: 917-932, 2016.

96. Fei P, Zhang Q, Huang L, Xu Y, Zhu X, Tai Z, Gong B, Ma S, Yao Q, Li J, et al: Identification of two novel LRP5 mutations in families with familial exudative vitreoretinopathy. Mol Vis 20: 395-409, 2014.

97. Ye X, Wang Y and Nathans J: The Norrin/Frizzled4 signaling pathway in retinal vascular development and disease. Trends Mol Med 16: 417-425, 2010.

98. Stenman JM, Rajagopal J, Carroll TJ, Ishibashi M, McMahon J and McMahon AP: Canonical Wnt signaling regulates organspecific assembly and differentiation of CNS vasculature. Science 322: 1247-1250, 2008.

99. Wang Z, Liu CH, Sun Y, Gong Y, Favazza TL, Morss PC Saba NJ, Fredrick TW, He X, Akula JD, et al: Pharmacologic activation of Wnt signaling by lithium normalizes retinal vasculature in a murine model of familial exudative vitreoretinopathy. Am J Pathol 186: 2588-2600, 2016.

100. Birdsey GM, Shah AV, Dufton N, Reynolds LE, Osuna Almagro L, Yang Y, Aspalter IM, Khan ST, Mason JC, Dejana E, et al: The endothelial transcription factor ERG promotes vascular stability and growth through $\mathrm{Wnt} / \beta$-catenin signaling. Dev Cell 32: 82-96, 2015.

101. Arthofer E, Hot B, Petersen J, Strakova K, Jäger S Grundmann M, Kostenis E, Gutkind JS and Schulte G: WNT stimulation dissociates a Frizzled 4 inactive-state complex with Ga12/13. Mol Pharmacol 90: 447-459, 2016

102. Adler PN: The frizzled/stan pathway and planar cell polarity in the Drosophila wing. Curr Top Dev Biol 101: 1-31, 2012.

103. Yang Y and Mlodzik M: Wnt-Frizzled/planar cell polarity signaling: Cellular orientation by facing the wind (Wnt). Annu Rev Cell Dev Biol 31: 623-646, 2015.

104. Gao B, Song H, Bishop K, Elliot G, Garrett L, English MA, Andre P, Robinson J, Sood R, Minami Y, et al: Wnt signaling gradients establish planar cell polarity by inducing Vangl2 phosphorylation through Ror2. Dev Cell 20: 163-176, 2011.

105. Nishimura T, Honda $\mathrm{H}$ and Takeichi M: Planar cell polarity links axes of spatial dynamics in neural-tube closure. Cell 149: 1084-1097, 2012.

106.Pan X, Sittaramane V, Gurung S and Chandrasekhar A: Structural and temporal requirements of Wnt/PCP protein Vangl2 function for convergence and extension movements and facial branchiomotor neuron migration in zebrafish. Mech Dev 131: 1-14, 2014.

107. Gödde NJ, Pearson HB, Smith LK and Humbert PO: Dissecting the role of polarity regulators in cancer through the use of mouse models. Exp Cell Res 328: 249-257, 2014.

108. Cantrell VA and Jessen JR: The planar cell polarity protein Van Gogh-Like 2 regulates tumor cell migration and matrix metalloproteinase-dependent invasion. Cancer Lett 287: 54-61, 2010.

109. O'Connell MP, Fiori JL, Xu M, Carter AD, Frank BP, Camilli TC, French AD, Dissanayake SK, Indig FE, Bernier M, et al: The orphan tyrosine kinase receptor, ROR2, mediates Wnt5A signaling in metastatic melanoma. Oncogene 29: 34-44, 2010

110. Wang W, Runkle KB, Terkowski SM, Ekaireb RI and Witze ES Protein depalmitoylation is induced by Wnt5a and promotes polarized cell behavior. J Biol Chem 290: 15707-15716, 2015.

111. Webster MR, Kugel CH III and Weeraratna AT: The Wnts of change: How Wnts regulate phenotype switching in melanoma. Biochim Biophys Acta 1856: 244-251, 2015.

112. Katoh M: Function and cancer genomics of FAT family genes (Review). Int J Oncol 41: 1913-1918, 2012.
113. Matis M and Axelrod JD: Regulation of PCP by the Fat signaling pathway. Genes Dev 27: 2207-2220, 2013.

114. Katoh $M$ and Katoh M: Identification and characterization of human PRICKLE1 and PRICKLE2 genes as well as mouse Prickle1 and Prickle2 genes homologous to Drosophila tissue polarity gene prickle. Int J Mol Med 11: 249-256, 2003.

115. De Marco P, Merello E, Piatelli G, Cama A, Kibar Z and Capra V: Planar cell polarity gene mutations contribute to the etiology of human neural tube defects in our population. Birth Defects Res A Clin Mol Teratol 100: 633-641, 2014

116. Allache R, Lachance S, Guyot MC, De Marco P, Merello E, Justice MJ, Capra V and Kibar Z: Novel mutations in Lrp6 orthologs in mouse and human neural tube defects affect a highly dosage-sensitive Wnt non-canonical planar cell polarity pathway. Hum Mol Genet 23: 1687-1699, 2014

117. Bassuk AG, Wallace RH, Buhr A, Buller AR, Afawi Z, Shimojo M, Miyata S, Chen S, Gonzalez-Alegre P, Griesbach HL, et al: A homozygous mutation in human PRICKLE1 causes an autosomal-recessive progressive myoclonus epilepsy-ataxia syndrome. Am J Hum Genet 83: 572-581, 2008.

118. Tao H, Manak JR, Sowers L, Mei X, Kiyonari H, Abe T, Dahdaleh NS, Yang T, Wu S, Chen S, et al: Mutations in prickle orthologs cause seizures in flies, mice, and humans. Am J Hum Genet 88: 138-149, 2011

119. Sowers LP, Loo L, Wu Y, Campbell E, Ulrich JD, Wu S, Paemka L, Wassink T, Meyer K, Bing X, et al: Disruption of the non-canonical Wnt gene PRICKLE2 leads to autism-like behaviors with evidence for hippocampal synaptic dysfunction. Mol Psychiatry 18: 1077-1089, 2013.

120. White JJ, Mazzeu JF, Hoischen A, Bayram Y, Withers M, Gezdirici A, Kimonis V, Steehouwer M, Jhangiani SN, Muzny DM, et al; Baylor-Hopkins Center for Mendelian Genomics: DVL3 alleles resulting in a -1 frameshift of the last exon mediate autosomal-dominant Robinow syndrome. Am J Hum Genet 98: 553-561, 2016.

121. Copp AJ and Greene ND: Genetics and development of neural tube defects. J Pathol 220: 217-230, 2010.

122. Muñoz-Soriano V, Belacortu Y and Paricio N: Planar cell polarity signaling in collective cell movements during morphogenesis and disease. Curr Genomics 13: 609-622, 2012

123. Wu G, Huang X, Hua Y and Mu D: Roles of planar cell polarity pathways in the development of neutral tube defects. J Biomed Sci 18: 66, 2011.

124. de laHozAB,MaortuaH,García-Rives A,Martínez-GonzálezMJ, Ezquerra M and Tejada MI: 3p14 de novo interstitial microdeletion in a patient with intellectual disability and autistic features with language impairment: A comparison with similar cases. Case Rep Genet 2015: 876348, 2015.

125. Mazzeu JF, Pardono E, Vianna-Morgante AM, Richieri-Costa A, Ae Kim C, Brunoni D, Martelli L, de Andrade CE, Colin G and Otto PA: Clinical characterization of autosomal dominant and recessive variants of Robinow syndrome. Am J Med Genet A 143: 320-325, 2007.

126. Person AD, Beiraghi S, Sieben CM, Hermanson S, Neumann AN, Robu ME, Schleiffarth JR, Billington CJ Jr, van Bokhoven $\mathrm{H}$, Hoogeboom JM, et al: WNT5A mutations in patients with autosomal dominant Robinow syndrome. Dev Dyn 239: 327-337, 2010.

127. Afzal AR, Rajab A, Fenske CD, Oldridge M, Elanko N, Ternes-Pereira E, Tüysüz B, Murday VA, Patton MA, Wilkie AO, et al: Recessive Robinow syndrome, allelic to dominant brachydactyly type $\mathrm{B}$, is caused by mutation of ROR2. Nat Genet 25 : 419-422, 2000.

128. Oldridge M, Fortuna AM, Maringa M, Propping P, Mansour S, Pollitt C, DeChiara TM, Kimble RB, Valenzuela DM, Yancopoulos GD, et al: Dominant mutations in ROR2, encoding an orphan receptor tyrosine kinase, cause brachydactyly type B. Nat Genet 24: 275-278, 2000.

129. Green JL, Kuntz SG and Sternberg PW: Ror receptor tyrosine kinases: Orphans no more. Trends Cell Biol 18: 536-544, 2008 .

130. Minami Y, Oishi I, Endo M and Nishita M: Ror-family receptor tyrosine kinases in noncanonical Wnt signaling: Their implications in developmental morphogenesis and human diseases. Dev Dyn 239: 1-15, 2010

131. Petrova IM, Malessy MJ, Verhaagen J, Fradkin LG and Noordermeer JN: Wnt signaling through the Ror receptor in the nervous system. Mol Neurobiol 49: 303-315, 2014.

132. Debebe $Z$ and Rathmell WK: Ror2 as a therapeutic target in cancer. Pharmacol Ther 150: 143-148, 2015. 
133. Bunn KJ, Lai A, Al-Ani A, Farella M, Craw S and Robertson SP: An osteosclerotic form of Robinow syndrome. Am J Med Genet A 164A: 2638-2642, 2014.

134.Liu C, Lin C, Gao C, May-Simera H, Swaroop A and Li T: Null and hypomorph Pricklel alleles in mice phenocopy human Robinow syndrome and disrupt signaling downstream of Wnt5a. Biol Open 3: 861-870, 2014.

135. Ford CE, Qian Ma SS, Quadir A and Ward RL: The dual role of the novel Wnt receptor tyrosine kinase, ROR2, in human carcinogenesis. Int J Cancer 133: 779-787, 2013

136. Asad M, Wong MK, Tan TZ, Choolani M, Low J, Mori S, Virshup D, Thiery JP and Huang RY: FZD7 drives in vitro aggressiveness in Stem-A subtype of ovarian cancer via regulation of non-canonical Wnt/PCP pathway. Cell Death Dis 5: e1346, 2014.

137. Qin L, Yin YT, Zheng FJ, Peng LX, Yang CF, Bao YN, Liang YY, Li XJ, Xiang YQ, Sun R, et al: WNT5A promotes stemness characteristics in nasopharyngeal carcinoma cells leading to metastasis and tumorigenesis. Oncotarget 6: 10239-10252, 2015.

138. Thiele S, Rachner TD, Rauner M and Hofbauer LC: WNT5A and its receptors in the bone-cancer dialogue. J Bone Miner Res 31: 1488-1496, 2016.

139. Kumawat K and Gosens R: WNT-5A: Signaling and functions in health and disease. Cell Mol Life Sci 73: 567-587, 2016.

140. Wei H, Wang N, Zhang Y, Wang S, Pang X and Zhang S: Wnt-11 overexpression promoting the invasion of cervical cancer cells. Tumour Biol 37: 11789-11798, 2016.

141. Arabzadeh S, Hossein G, Salehi-Dulabi Z and Zarnani AH: WNT5A-ROR2 is induced by inflammatory mediators and is involved in the migration of human ovarian cancer cell line SKOV-3. Cell Mol Biol Lett 21: 9, 2016.

142. Jiang W, Crossman DK, Mitchell EH, Sohn P, Crowley MR and Serra R: WNT5A inhibits metastasis and alters splicing of Cd44 in breast cancer cells. PLoS One 8: e58329, 2013.

143. Easter SL, Mitchell EH, Baxley SE, Desmond R, Frost AR and Serra R: Wnt5a suppresses tumor formation and redirects tumor phenotype in MMTV-Wnt1 tumors. PLoS One 9: e113247, 2014.

144. Wang MT, Holderfield M, Galeas J, Delrosario R, To MD, Balmain A and McCormick F: K-Ras promotes tumorigenicity through suppression of non-canonical Wnt signaling. Cell 163: $1237-1251,2015$.

145. Fukuda T, Chen L, Endo T, Tang L, Lu D, Castro JE, Widhopf GF II, Rassenti LZ, Cantwell MJ, Prussak CE, et al: Antiserainduced by infusions of autologous Ad-CD154-leukemia B cells identify ROR 1 as an oncofetal antigen and receptor for Wnt5a. Proc Natl Acad Sci USA 105: 3047-3052, 2008.

146. Bicocca VT, Chang BH, Masouleh BK, Muschen M, Loriaux MM, Druker BJ and Tyner JW: Crosstalk between ROR1 and the Pre-B cell receptor promotes survival of $t(1 ; 19)$ acute lymphoblastic leukemia. Cancer Cell 22: 656-667, 2012.

147. Yu J, Chen L, Cui B, Widhopf GF II, Shen Z, Wu R, Zhang L, Zhang S, Briggs SP and Kipps TJ: Wnt5a induces ROR1/ROR2 heterooligomerization to enhance leukemia chemotaxis and proliferation. J Clin Invest 126: 585-598, 2016.

148. Gentile A, Lazzari L, Benvenuti S, Trusolino L and Comoglio PM The ROR1 pseudokinase diversifies signaling outputs in MET-addicted cancer cells. Int J Cancer 135: 2305-2316, 2014.

149. Hojjat-Farsangi M, Moshfegh A, Daneshmanesh AH, Khan AS, Mikaelsson E, Osterborg A and Mellstedt $\mathrm{H}$ : The receptor tyrosine kinase ROR1 - an oncofetal antigen for targeted cancer therapy. Semin Cancer Biol 29: 21-31, 2014

150.Li C, Wang S, Xing Z, Lin A, Liang K, Song J, Hu Q, Yao J, Chen Z, Park PK, et al: A ROR1-HER3-lncRNA signalling axis modulates the Hippo-YAP pathway to regulate bone metastasis. Nat Cell Biol 19: 106-119, 2017.

151. Widhopf GF II, Cui B, Ghia EM, Chen L, Messer K, Shen Z, Briggs SP, Croce CM and Kipps TJ: ROR1 can interact with TCL1 and enhance leukemogenesis in E $\mu$-TCL1 transgenic mice. Proc Natl Acad Sci USA 111: 793-798, 2014.

152. Yamaguchi T, Lu C, Ida L, Yanagisawa K, Usukura J, Cheng J, Hotta N, Shimada Y, Isomura H, Suzuki M, et al: ROR1 sustains caveolae and survival signalling as a scaffold of cavin-1 and caveolin-1. Nat Commun 7: 10060, 2016.

153. O'Connell MP, Marchbank K, Webster MR, Valiga AA, Kaur A, Vultur A, Li L, Herlyn M, Villanueva J, Liu Q, et al: Hypoxia induces phenotypic plasticity and therapy resistance in melanoma via the tyrosine kinase receptors ROR1 and ROR2. Cancer Discov 3: 1378-1393, 2013.

154.Lai SS, Xue B, Yang Y, Zhao L, Chu CS, Hao JY and Wen CJ: Ror2-Src signaling in metastasis of mouse melanoma cells is inhibited by NRAGE. Cancer Genet 205: 552-562, 2012.
155. Niemann S, Zhao C, Pascu F, Stahl U, Aulepp U, Niswander L, Weber JL and Müller U: Homozygous WNT3 mutation causes tetra-amelia in a large consanguineous family. Am J Hum Genet 74: 558-563, 2004.

156. Woods CG, Stricker S, Seemann P, Stern R, Cox J, Sherridan E, Roberts E, Springell K, Scott S, Karbani G, et al: Mutations in $W N T 7 A$ cause a range of limb malformations, including Fuhrmann syndrome and Al-Awadi/Raas-Rothschild/Schinzel phocomelia syndrome. Am J Hum Genet 79: 402-408, 2006.

157. Biason-Lauber A, Konrad D, Navratil F and Schoenle EJ: A WNT4 mutation associated with Müllerian-duct regression and virilization in a 46,XX woman. N Engl J Med 351: 792-798, 2004.

158. Mandel H, Shemer R, Borochowitz ZU, Okopnik M, Knopf C, Indelman M, Drugan A, Tiosano D, Gershoni-Baruch R, Choder M, et al: SERKAL syndrome: An autosomal-recessive disorder caused by a loss-of-function mutation in WNT4. Am J Hum Genet 82: 39-47, 2008.

159. Kirikoshi H, Sekihara $\mathrm{H}$ and Katoh M: WNT10A and WNT6, clustered in human chromosome $2 \mathrm{q} 35$ region with head-to-tail manner, are strongly coexpressed in SW480 cells. Biochem Biophys Res Commun 283: 798-805, 2001.

160. Adaimy L, Chouery E, Megarbane H, Mroueh S, Delague V, Nicolas E, Belguith $\mathrm{H}$, de Mazancourt $\mathrm{P}$ and Megarbane A: Mutation in WNT10A is associated with an autosomal recessive ectodermal dysplasia: The odonto-onycho-dermal dysplasia. Am J Hum Genet 81: 821-828, 2007.

161. van den Boogaard MJ, Créton M, Bronkhorst Y, van der Hout A, Hennekam E, Lindhout D, Cune M and Ploos van Amstel HK: Mutations in WNT1OA are present in more than half of isolated hypodontia cases. J Med Genet 49: 327-331, 2012.

162. Yu P, Yang W, Han D, Wang X, Guo S, Li J, Li F, Zhang X, Wong SW, Bai B, et al: Mutations in WNT1OB are identified in individuals with oligodontia. Am J Hum Genet 99: 195-201, 2016.

163. Massink MP, Créton MA, Spanevello F, Fennis WM, Cune MS, Savelberg SM, Nijman IJ, Maurice MM, van den Boogaard MJ and van Haaften G: $\mathrm{H}$ and van Haaften G: Loss-of-function mutations in the WNT co-receptor LRP6 cause autosomaldominant oligodontia. Am J Hum Genet 97: 621-626, 2015.

164. Poulsen A, Ho SY, Wang W, Alam J, Jeyaraj DA, Ang SH, Tan ES, Lin GR, Cheong VW, Ke Z, et al: Pharmacophore model for Wnt/Porcupine inhibitors and its use in drug design. J Chem Inf Model 55: 1435-1448, 2015.

165. Grzeschik KH, Bornholdt D, Oeffner F, König A, del Carmen Boente M, Enders H, Fritz B, Hertl M, Grasshoff U, Höfling K, et al: Deficiency of PORCN, a regulator of Wnt signaling, is associated with focal dermal hypoplasia. Nat Genet 39: 833-835, 2007.

166. Liu C,Widen SA, Williamson KA, Ratnapriya R, Gerth-KahlertC, Rainger J, Alur RP, Strachan E, Manjunath SH, Balakrishnan A, et al; UK10K Consortium: A secreted WNT-ligand-binding domain of FZD5 generated by a frameshift mutation causes autosomal dominant coloboma. Hum Mol Genet 25: 1382-1391, 2016.

167. Fröjmark AS, Schuster J, Sobol M, Entesarian M, Kilander MB Gabrikova D, Nawaz S, Baig SM, Schulte G, Klar J, et al: Mutations in Frizzled 6 cause isolated autosomal-recessive nail dysplasia. Am J Hum Genet 88: 852-860, 2011.

168. Parma P, Radi O, Vidal V, Chaboissier MC, Dellambra E, Valentini S, Guerra L, Schedl A and Camerino G: R-spondin1 is essential in sex determination, skin differentiation and malignancy. Nat Genet 38: 1304-1309, 2006.

169. Brüchle NO, Frank J, Frank V, Senderek J, Akar A, Koc E, Rigopoulos D, van Steensel M, Zerres K and Bergmann C: RSPO4 is the major gene in autosomal-recessive anonychia and mutations cluster in the furin-like cysteine-rich domains of the Wnt signaling ligand R-spondin 4. J Invest Dermatol 128: 791-796, 2008

170. Ekici AB, Hilfinger D, Jatzwauk M, Thiel CT, Wenzel D, Lorenz I, Boltshauser E, Goecke TW, Staatz G, Morris-Rosendahl DJ, et al: Disturbed Wnt signalling due to a mutation in CCDC $88 C$ causes an autosomal recessive non-syndromic hydrocephalus with medial diverticulum. Mol Syndromol 1: 99-112, 2010.

171. Aznar N, Midde KK, Dunkel Y, Lopez-Sanchez I, Pavlova Y, Marivin A, Barbazán J, Murray F, Nitsche U, Janssen KP, et al: Daple is a novel non-receptor GEF required for trimeric $\mathrm{G}$ protein activation in Wnt signaling. eLife 4: e07091, 2015.

172. Voronkov A and Krauss S: Wnt/ $\beta$-catenin signaling and small molecule inhibitors. Curr Pharm Des 19: 634-664, 2013. 
173. Takebe N, Miele L, Harris PJ, Jeong W, Bando H, Kahn M, Yang SX and Ivy SP: Targeting Notch, Hedgehog, and Wnt pathways in cancer stem cells: Clinical update. Nat Rev Clin Oncol 12: 445-464, 2015.

174. Tai D, Wells K, Arcaroli J, Vanderbilt C, Aisner DL, Messersmith WA and Lieu CH: Targeting the WNT signaling pathway in cancer therapeutics. Oncologist 20: 1189-1198, 2015.

175. Pelay-Gimeno M, Glas A, Koch O and Grossmann TN: Structure-based design of inhibitors of protein-protein interactions: Mimicking peptide binding epitopes. Angew Chem Int Ed Engl 54: 8896-8927, 2015.

176. Kakugawa S, Langton PF, Zebisch M, Howell SA, Chang TH, Liu Y, Feizi T, Bineva G, O'Reilly N, Snijders AP, et al: Notum deacylates Wnt proteins to suppress signalling activity. Nature 519: 187-192, 2015

177. Madan B, Ke Z, Harmston N, Ho SY, Frois AO, Alam J, Jeyaraj DA, Pendharkar V, Ghosh K, Virshup IH, et al: Wnt addiction of genetically defined cancers reversed by PORCN inhibition. Oncogene 35: 2197-2207, 2016.

178. Chen B, Dodge ME, Tang W, Lu J, Ma Z, Fan CW, Wei S, Hao W, Kilgore J, Williams NS, et al: Small molecule-mediated disruption of Wnt-dependent signaling in tissue regeneration and cancer. Nat Chem Biol 5: 100-107, 2009.

179.Liu J, Pan S, Hsieh MH, Ng N, Sun F, Wang T, Kasibhatla S, Schuller AG, Li AG, Cheng D, et al: Targeting Wnt-driven cancer through the inhibition of Porcupine by LGK974. Proc Natl Acad Sci USA 110: 20224-20229, 2013

180. Proffitt KD, Madan B, Ke Z, Pendharkar V, Ding L, Lee MA Hannoush RN and Virshup DM: Pharmacological inhibition of the Wnt acyltransferase PORCN prevents growth of WNT-driven mammary cancer. Cancer Res 73: 502-507, 2013.

181.van de Wetering M, Francies HE, Francis JM, Bounova G, Iorio F, Pronk A, van Houdt W, van Gorp J, Taylor-Weiner A, Kester L, et al: Prospective derivation of a living organoid biobank of colorectal cancer patients. Cell 161: 933-945, 2015.

182. Cheng Y, Phoon YP, Jin X, Chong SY, Ip JC, Wong BW and Lung ML: Wnt-C59 arrests stemness and suppresses growth of nasopharyngeal carcinoma in mice by inhibiting the Wnt pathway in the tumor microenvironment. Oncotarget 6 : $14428-14439,2015$.

183. Madan B, Ke Z, Lei ZD, Oliver FA, Oshima M, Lee MA, Rozen S and Virshup DM: NOTUM is a potential pharmacodynamic biomarker of Wnt pathway inhibition. Oncotarget 7: 12386-12392, 2016

184. Blyszczuk P, Müller-Edenborn B, Valenta T, Osto E, Stellato M, Behnke S, Glatz K, Basler K, Lüscher TF, Distler O, et al: Transforming growth factor- $\beta$-dependent Wnt secretion controls myofibroblast formation and myocardial fibrosis progression in experimental autoimmune myocarditis. Eur Heart J 38: 1413-1425, 2017.

185. Madan B, Patel MB, Zhang J, Bunte RM, Rudemiller NP, Griffiths R, Virshup DM and Crowley SD: Experimental inhibition of porcupine-mediated Wnt O-acylation attenuates kidney fibrosis. Kidney Int 89: 1062-1074, 2016.

186. Diamond JR, Eckhardt SG, Bendell JC, Munster P, Morris VK, Kopetz S, Cattaruzza F, Kapoun AM, Dupont J and Faoro L: A Phase $1 \mathrm{a} / \mathrm{b}$ study of OMP-131R10, an anti-RSPO3 antibody, in advanced solid tumors and previously treated metastatic colorectal cancer (CRC). Presented at: TAT 2016 Conference. Washington DC, 21-23 March, 2016.

187.Katoh M, Hirai M, Sugimura T and Terada M: Cloning, expression and chromosomal localization of Wnt-13, a novel member of the Wnt gene family. Oncogene 13: 873-876, 1996

188. Katoh M, Kirikoshi H, Terasaki $\mathrm{H}$ and Shiokawa K: WNT2B2 mRNA, upregulated in primary gastric cancer, is a positive regulator of the WNT- $\beta$-catenin-TCF signaling pathway. Biochem Biophys Res Commun 289: 1093-1098, 2001.

189. Jiang H, Li F, He C, Wang X, Li Q and Gao H: Expression of Gli1 and Wnt2B correlates with progression and clinical outcome of pancreatic cancer. Int J Clin Exp Pathol 7: 4531-4538, 2014

190.Li G, Liu Y, Su Z, Ren S, Zhu G, Tian Y and Qiu Y: MicroRNA324-3p regulates nasopharyngeal carcinoma radioresistance by directly targeting WNT2B. Eur J Cancer 49: 2596-2607, 2013.

191.Li SJ, Yang XN and Qian HY: Antitumor effects of WNT2B silencing in GLUT1 overexpressing cisplatin resistant head and neck squamous cell carcinoma. Am J Cancer Res 5: 300-308, 2014.

192. Kobayashi M, Huang CL, Sonobe M, Kikuchi R and Date H: Ad-shWnt2b vector therapy demonstrates antitumor activity in orthotopic intrapleural models as monitored with the in vitro imaging system (IVIS). Anticancer Res 36: 5887-5893, 2016.
193. Tokuhara M, Hirai M, Atomi Y, Terada M and Katoh M: Molecular cloning of human Frizzled-6. Biochem Biophys Res Commun 243: 622-627, 1998.

194. Cantilena S, Pastorino F, Pezzolo A, Chayka O, Pistoia V, Ponzoni M and Sala A: Frizzled receptor 6 marks rare, highly tumourigenic stem-like cells in mouse and human neuroblastomas. Oncotarget 2: 976-983, 2011.

195. Kim BK, Yoo HI, Kim I, Park J and Kim Yoon S: FZD6 expression is negatively regulated by miR-199a-5p in human colorectal cancer. BMB Rep 48: 360-366, 2015.

196. Corda G, Sala G, Lattanzio R, Iezzi M, Sallese M, Fragassi G, Lamolinara A, Mirza H, Barcaroli D, Ermler S, et al: Functional and prognostic significance of the genomic amplification of frizzled 6 (FZD6) in breast cancer. J Pathol 241: 350-361, 2017.

197. Saitoh T, Hirai M and Katoh M: Molecular cloning and characterization of human Frizzled-5 gene on chromosome 2q33.3-q34 region. Int J Oncol 19: 105-110, 2001.

198. Steinhart Z, Pavlovic Z, Chandrashekhar M, Hart T, Wang X, Zhang X, Robitaille M, Brown KR, Jaksani S, Overmeer R, et al: Genome-wide CRISPR screens reveal a Wnt-FZD5 signaling circuit as a druggable vulnerability of RNF43-mutant pancreatic tumors. Nat Med 23: 60-68, 2017.

199. Sagara N, Toda G, Hirai M, Terada M and Katoh M: Molecular cloning, differential expression, and chromosomal localization of human frizzled-1, frizzled-2, and frizzled-7. Biochem Biophys Res Commun 252: 117-122, 1998.

200. Simmons GE Jr, Pandey S, Nedeljkovic-Kurepa A, Saxena M, Wang A and Pruitt K: Frizzled 7 expression is positively regulated by SIRT1 and $\beta$-catenin in breast cancer cells. PLoS One 9: e98861, 2014.

201. Vincan E, Flanagan DJ, Pouliot N, Brabletz T and Spaderna S: Variable $F Z D 7$ expression in colorectal cancers indicates regulation by the tumour microenvironment. Dev Dyn 239: 311-317, 2010.

202. Qiu X, Jiao J, Li Y and Tian T: Overexpression of $F Z D 7$ promotes glioma cell proliferation by upregulating TAZ. Oncotarget 7: 85987-85999, 2016

203. Song J, Gao L, Yang G, Tang S, Xie H, Wang Y, Wang J, Zhang Y, Jin J, Gou Y, et al: MiR-199a regulates cell proliferation and survival by targeting FZD7. PLoS One 9: e110074, 2014.

204. Koike J, Takagi A, Miwa T, Hirai M, Terada M and Katoh M: Molecular cloning of Frizzled-10, a novel member of the Frizzled gene family. Biochem Biophys Res Commun 262: 39-43, 1999.

205. Gong C, Qu S, Lv XB, Liu B, Tan W, Nie Y, Su F, Liu Q, Yao H and Song E: BRMS1L suppresses breast cancer metastasis by inducing epigenetic silence of FZD10. Nat Commun 5: 5406, 2014.

206. Terasaki H, Saitoh T, Shiokawa K and Katoh M: Frizzled-10, upregulated in primary colorectal cancer, is a positive regulator of the WNT- $\beta$-catenin-TCF signaling pathway. Int J Mol Med 9: $107-112,2002$

207. Hanaoka H, Katagiri T, Fukukawa C, Yoshioka H, Yamamoto S, Iida Y, Higuchi T, Oriuchi N, Paudyal B, Paudyal P, et al: Radioimmunotherapy of solid tumors targeting a cell-surface protein, FZD10: Therapeutic efficacy largely depends on radiosensitivity. Ann Nucl Med 23: 479-485, 2009.

208. Gurney A, Axelrod F, Bond CJ, Cain J, Chartier C, Donigan L, Fischer M, Chaudhari A, Ji M, Kapoun AM, et al: Wnt pathway inhibition via the targeting of Frizzled receptors results in decreased growth and tumorigenicity of human tumors. Proc Natl Acad Sci USA 109: 11717-11722, 2012.

209. Nielsen TO, Poulin NM and Ladanyi M: Synovial sarcoma: Recent discoveries as a roadmap to new avenues for therapy. Cancer Discov 5: 124-134, 2015.

210. Le PN, McDermott JD and Jimeno A: Targeting the Wnt pathway in human cancers: Therapeutic targeting with a focus on OMP-54F28. Pharmacol Ther 146: 1-11, 2015.

211. Ferreira Tojais N, Peghaire C, Franzl N, Larrieu-Lahargue F, Jaspard B, Reynaud A, Moreau C, Couffinhal T, Duplàa C and Dufourcq P: Frizzled7 controls vascular permeability through the Wnt-canonical pathway and crosstalk with endothelial cell junction complexes. Cardiovasc Res 103: 291-303, 2014.

212. Phesse T, Flanagan D and Vincan E: Frizzled7: A promising Achilles' heel for targeting the Wnt receptor complex to treat cancer. Cancers (Basel) 8: 50, 2016.

213. Katoh M: FGFR inhibitors: Effects on cancer cells, tumor microenvironment and whole-body homeostasis (Review). Int J Mol Med 38: 3-15, 2016

214. Shabani M and Hojjat-Farsangi M: Targeting receptor tyrosine kinases using monoclonal antibodies: The most specific tools for targeted-based cancer therapy. Curr Drug Targets 17: 1687-1703, 2016 . 
215.Gentile A, Lazzari L, Benvenuti S, Trusolino L and Comoglio PM: Ror1 is a pseudokinase that is crucial for Met-driven tumorigenesis. Cancer Res 71: 3132-3141, 2011.

216. Mellstedt H, Hojjat-Farsangi M, Daneshmanesh $\mathrm{AH}$ Moshfegh A, Byström S, Norin M, Olin T, Schultz J, Vågberg J and Österborg A: First generation of a small chemical molecule ROR1 RTK tyrosine kinase inhibitor. Ann Oncol 27 (Suppl 6): 1533P, 2016.

217. Khan AS, Hojjat-Farsangi M, Daneshmanesh AH, Hansson L, Kokhaei P, Osterborg A, Mellstedt $\mathrm{H}$ and Moshfegh A: Dishevelled proteins are significantly upregulated in chronic lymphocytic leukaemia. Tumour Biol 37: 11947-11957, 2016.

218. Barat B, Chichili G, Ciccarone V, Tamura J, Gorlatov S, Spliedt M, Chen F, Koenig S, Moore P, Bonvini E, et al: Development of a humanized ROR1 x CD3 bispecific DART molecule for the treatment of solid and liquid tumors. (Abstract). In: Proceedings of the 107th Annual Meeting of the American Association for Cancer Research; Apr 16-20, 2016. New Orleans, LA. Philadelphia. AACR. Cancer Res 76 (Suppl 14). Abstract 1489, 2016.

219. Blankenship JW, Misher L, Mitchell D, Zhang N, Tan P, Hoyos GH, Ravikumar P, Bader R, McMahan CJ, Miller RE, et al: Anti-ROR1 $\mathrm{x}$ anti-CD3 ADAPTIR ${ }^{\mathrm{TM}}$ molecule, ES425, redirects T-cell cytotoxicity and inhibits tumor growth in preclinical models of triple-negative breast cancer. (Abstract). In: Proceedings of the 107th Annual Meeting of the American Association for Cancer Research; Apr 16-20, 2016. New Orleans, LA. Philadelphia. AACR. Cancer Res 76 (Suppl 14). Abstract 4995, 2016.

220. Berger C, Sommermeyer D, Hudecek M, Berger M, Balakrishnan A, Paszkiewicz PJ, Kosasih PL, Rader C and Riddell SR: Safety of targeting ROR1 in primates with chimeric antigen receptor-modified T cells. Cancer Immunol Res 3: 206-216, 2015.

221. Tian E, Zhan F, Walker R, Rasmussen E, Ma Y, Barlogie B and Shaughnessy JD Jr: The role of the Wnt-signaling antagonist DKK1 in the development of osteolytic lesions in multiple myeloma. N Engl J Med 349: 2483-2494, 2003.

222. Voorzanger-Rousselot N, Goehrig D, Journe F, Doriath V, Body JJ, Clézardin P and Garnero P: Increased Dickkopf-1 expression in breast cancer bone metastases. Br J Cancer 97: 964-970, 2007.

223. McClung MR, Grauer A, Boonen S, Bolognese MA, Brown JP, Diez-Perez A, Langdahl BL, Reginster JY, Zanchetta JR Wasserman SM, et al: Romosozumab in postmenopausal women with low bone mineral density. N Engl J Med 370: 412-420, 2014

224. Recker RR, Benson CT, Matsumoto T, Bolognese MA, Robins DA, Alam J, Chiang AY, Hu L, Krege JH, Sowa H, et al: A randomized, double-blind phase 2 clinical trial of blosozumab, a sclerostin antibody, in postmenopausal women with low bone mineral density. J Bone Miner Res 30: 216-224, 2015.

225. Roschger A, Roschger P, Keplingter P, Klaushofer K, Abdullah S, Kneissel $M$ and Rauch F: Effect of sclerostin antibody treatment in a mouse model of severe osteogenesis imperfecta. Bone 66: $182-188,2014$

226. Fulciniti M, Tassone P, Hideshima T, Vallet S, Nanjappa $P$, Ettenberg SA, Shen Z, Patel N, Tai YT, Chauhan D, et al: Anti-DKK1 mAb (BHQ880) as a potential therapeutic agent for multiple myeloma. Blood 114: 371-379, 2009.

227. Bendell JC, Murphy JE, Mahalingam D, Halmos B, Sirard CA, Landau SB and Ryan DP: A Phase 1 study of DKN-01, an anti-DKK1 antibody, in combination with paclitaxel (pac) in patients with DKK1 relapsed or refractory esophageal cancer (EC) or gastro-esophageal junction tumors (GEJ). J Clin Oncol 34 (Suppl 4S): Abstract 111, 2016.

228. Betts AM, Clark TH, Yang J, Treadway JL, Li M, Giovanelli MA, Abdiche Y, Stone DM and Paralkar VM: The application of target information and preclinical pharmacokinetic/pharmacodynamic modeling in predicting clinical doses of a Dickkopf- 1 antibody for osteoporosis. J Pharmacol Exp Ther 333: 2-13, 2010.

229. Florio M, Gunasekaran K, Stolina M, Li X, Liu L, Tipton B, Salimi-Moosavi H, Asuncion FJ, Li C, Sun B, et al: A bispecific antibody targeting sclerostin and DKK-1 promotes bone mass accrual and fracture repair. Nat Commun 7: 11505, 2016.

230.Liu $\mathrm{C}$ and $\mathrm{Yu} \mathrm{X}$ : ADP-ribosyltransferases and poly ADP-ribosylation. Curr Protein Pept Sci 16: 491-501, 2015.

231. Katoh $\mathrm{M}$ and Katoh M: Identification and characterization of human TIPARP gene within the $C C N L$ amplicon at human chromosome 3q25.31. Int J Oncol 23: 541-547, 2003.
232. Roper SJ, Chrysanthou S, Senner CE, Sienerth A, Gnan S, Murray A, Masutani M, Latos $\mathrm{P}$ and Hemberger $\mathrm{M}$ : ADP-ribosyltransferases Parp1 and Parp7 safeguard pluripotency of ES cells. Nucleic Acids Res 42: 8914-8927, 2014

233. Haince JF, Rouleau M, Hendzel MJ, Masson JY and Poirier GG: Targeting poly(ADP-ribosyl)ation: A promising approach in cancer therapy. Trends Mol Med 11: 456-463, 2005.

234. Gunderson CC and Moore KN: Olaparib: An oral PARP-1 and PARP-2 inhibitor with promising activity in ovarian cancer. Future Oncol 11: 747-757, 2015.

235. Nathubhai A, Haikarainen T, Koivunen J, Murthy S, Koumanov F, Lloyd MD, Holman GD, Pihlajaniemi T, Tosh D, Lehtiö L, et al: Highly potent and isoform selective dual site binding tankyrase/Wnt signaling inhibitors that increase cellular glucose uptake and have antiproliferative activity. J Med Chem 60: 814-820, 2017.

236. Riffell JL, Lord CJ and Ashworth A: Tankyrase-targeted therapeutics: Expanding opportunities in the PARP family. Nat Rev Drug Discov 11: 923-936, 2012.

237. Wang W, Li N, Li X, Tran MK, Han X and Chen J: Tankyrase inhibitors target YAP by stabilizing angiomotin family proteins. Cell Rep 13: 524-532, 2015.

238. Kulak O, Chen H, Holohan B, Wu X, He H, Borek D, Otwinowski Z, Yamaguchi K, Garofalo LA, Ma Z, et al: Disruption of Wnt/ $\beta$-catenin signaling and telomeric shortening are inextricable consequences of tankyrase inhibition in human cells. Mol Cell Biol 35: 2425-2435, 2015.

239. Scarborough HA, Helfrich BA, Casás-Selves M, Schuller AG, Grosskurth SE, Kim J, Tan AC, Chan DC, Zhang Z, Zaberezhnyy V, et al: AZ1366: An inhibitor of tankyrase and the canonical Wnt pathway that limits the persistence of non-small cell lung cancer cells following EGFR inhibition. Clin Cancer Res 23: 1531-1541, 2017.

240. Lau T, Chan E, Callow M, Waaler J, Boggs J, Blake RA, Magnuson S, Sambrone A, Schutten M, Firestein R, et al: A novel tankyrase small-molecule inhibitor suppresses APC mutation-driven colorectal tumor growth. Cancer Res 73: 3132-3144, 2013

241. Shultz MD, Cheung AK, Kirby CA, Firestone B, Fan J, Chen CH, Chen Z, Chin DN, Dipietro L, Fazal A, et al: Identification of NVP-TNKS656: The use of structure-efficiency relationships to generate a highly potent, selective, and orally active tankyrase inhibitor. J Med Chem 56: 6495-6511, 2013.

242. Arqués O, Chicote I, Puig I, Tenbaum SP, Argilés G, Dienstmann R, Fernández N, Caratù G, Matito J, Silberschmidt D, et al: Tankyrase inhibition blocks $\mathrm{Wnt} / \beta$-catenin pathway and reverts resistance to PI $3 \mathrm{~K}$ and AKT inhibitors in the treatment of colorectal cancer. Clin Cancer Res 22: 644-656, 2016.

243. Huang SM, Mishina YM, Liu S, Cheung A, Stegmeier F, Michaud GA, Charlat O, Wiellette E, Zhang Y, Wiessner S, et al: Tankyrase inhibition stabilizes axin and antagonizes Wnt signalling. Nature 461: 614-620, 2009.

244. Casás-Selves M, Kim J, Zhang Z, Helfrich BA, Gao D, Porter CC Scarborough HA, Bunn PA Jr, Chan DC, Tan AC, et al: Tankyrase and the canonical Wnt pathway protect lung cancer cells from EGFR inhibition. Cancer Res 72: 4154-4164, 2012.

245. Feng W, Teng R, Zhao Y, Gao J and Chu H: Epigenetic modulation of Wnt signaling contributes to neuropathic pain in rats. Mol Med Rep 12: 4727-4733, 2015.

246. Meijer L, Skaltsounis AL, Magiatis P, Polychronopoulos P, Knockaert M, Leost M, Ryan XP, Vonica CA, Brivanlou A, Dajani R, et al: GSK-3-selective inhibitors derived from Tyrian purple indirubins. Chem Biol 10: 1255-1266, 2003.

247. Wu Y, Ai Z, Yao K, Cao L, Du J, Shi X, Guo Z and Zhang Y: CHIR99021 promotes self-renewal of mouse embryonic stem cells by modulation of protein-encoding gene and long intergenic non-coding RNA expression. Exp Cell Res 319: 2684-2699, 2013.

248. Atkinson JM, Rank KB, Zeng Y, Capen A, Yadav V, Manro JR, Engler TA and Chedid M: Activating the Wnt/ $\beta$-catenin pathway for the treatment of melanoma: Application of LY2090314, a novel selective inhibitor of glycogen synthase kinase-3. PLoS One 10: e0125028, 2015.

249. Ding S, Wu TY, Brinker A, Peters EC, Hur W, Gray NS and Schultz PG: Synthetic small molecules that control stem cell fate. Proc Natl Acad Sci USA 100: 7632-7637, 2003.

250. Lalit PA, Salick MR, Nelson DO, Squirrell JM, Shafer CM, Patel NG, Saeed I, Schmuck EG, Markandeya YS, Wong R, et al: Lineage reprogramming of fibroblasts into proliferative induced cardiac progenitor cells by defined factors. Cell Stem Cell 18: 354-367, 2016 
251. Narcisi R, Arikan OH,Lehmann J, Ten Berge D and van Osch GJ: Differential effects of small molecule WNT agonists on the multilineage differentiation capacity of human mesenchymal stem cells. Tissue Eng Part A 22: 1264-1273, 2016.

252. Fiskus W, Sharma S, Saha S, Shah B, Devaraj SG, Sun B, Horrigan S, Leveque C, Zu Y, Iyer S, et al: Pre-clinical efficacy of combined therapy with novel $\beta$-catenin antagonist BC2059 and histone deacetylase inhibitor against AML cells. Leukemia 29: $1267-1278,2015$

253. Trautmann M, Sievers E, Aretz S, Kindler D, Michels S, Friedrichs N, Renner M, Kirfel J, Steiner S, Huss S, et al: SS18-SSX fusion protein-induced Wnt/ $\beta$-catenin signaling is a therapeutic target in synovial sarcoma. Oncogene 33: 5006-5016, 2014

254.Jang GB, Hong IS, Kim RJ, Lee SY, Park SJ, Lee ES, Park JH, Yun $\mathrm{CH}$, Chung JU, Lee KJ, et al: Wnt/ $\beta$-catenin small-molecule inhibitor CWP232228 preferentially inhibits the growth of breast cancer stem-like cells. Cancer Res 75: 1691-1702, 2015.

255.Emami KH, Nguyen C, Ma H, Kim DH, Jeong KW, Eguchi M, Moon RT, Teo JL, Kim HY, Moon SH, et al: A small molecule inhibitor of $\beta$-catenin/CREB-binding protein transcription [corrected]. Proc Natl Acad Sci USA 101: 12682-12687, 2004.

256. Fang L,Zhu Q, Neuenschwander M, SpeckerE, Wulf-Goldenberg A, Weis WI, von Kries JP and Birchmeier W: A small-molecule antagonist of the $\beta$-catenin/TCF4 interaction blocks the selfrenewal of cancer stem cells and suppresses tumorigenesis. Cancer Res 76: 891-901, 2016.

257. Hwang SY, Deng X, Byun S, Lee C, Lee SJ, Suh H, Zhang J, Kang Q, Zhang T, Westover KD, et al: Direct targeting of $\beta$-catenin by a small molecule stimulates proteasomal degradation and suppresses oncogenic Wnt/ $\beta$-catenin signaling. Cell Rep 16: 28-36, 2016.

258. Sukhdeo K, Mani M, Zhang Y, Dutta J, Yasui H, Rooney MD, Carrasco DE, Zheng M, He H, Tai YT, et al: Targeting the $\beta$-catenin/TCF transcriptional complex in the treatment of multiple myeloma. Proc Natl Acad Sci USA 104: 7516-7521, 2007.

259. Lenz HJ and Kahn M: Safely targeting cancer stem cells via selective catenin coactivator antagonism. Cancer Sci 105 1087-1092, 2014.

260. Takada K, Zhu D, Bird GH, Sukhdeo K, Zhao JJ, Mani M, Lemieux M, Carrasco DE, Ryan J, Horst D, et al: Targeted disruption of the BCL9/ $\beta$-catenin complex inhibits oncogenic Wnt signaling. Sci Transl Med 4: 148ra117, 2012.

261.Henderson WR Jr, Chi EY, Ye X, Nguyen C, Tien YT, Zhou B, Borok Z, Knight DA and Kahn M: Inhibition of Wnt/ beta-catenin/CREB binding protein (CBP) signaling reverses pulmonary fibrosis. Proc Natl Acad Sci USA 107: 14309-14314, 2010.

262.Zhou L, Li Y, Hao S, Zhou D, Tan RJ, Nie J, Hou FF, Kahn M and Liu Y: Multiple genes of the renin-angiotensin system are novel targets of Wnt/ $\beta$-catenin signaling. J Am Soc Nephrol 26 $107-120,2015$

263. Gajewski TF, Schreiber H and Fu YX: Innate and adaptive immune cells in the tumor microenvironment. Nat Immunol 14 1014-1022, 2013.

264. Son B, Lee S, Youn H, Kim E, Kim W and Youn B: The role of tumor microenvironment in therapeutic resistance. Oncotarget 8: 3933-3945, 2017.

265. Spranger S, Bao R and Gajewski TF: Melanoma-intrinsic $\beta$-catenin signalling prevents anti-tumour immunity. Nature 523 231-235, 2015.
266. Malladi S, Macalinao DG, Jin X, He L, Basnet H, Zou Y, de Stanchina E and Massagué J: Metastatic latency and immune evasion through autocrine Inhibition of WNT. Cell 165: 45-60, 2016.

267. Xu WD, Wang J, Yuan TL, Li YH, Yang H, Liu Y, Zhao Y and Herrmann M: Interactions between canonical Wnt signaling pathway and MAPK pathway regulate differentiation, maturation and function of dendritic cells. Cell Immunol 310: 170-177, 2016.

268. Naskar D, Maiti G, Chakraborty A, Roy A, Chattopadhyay D and Sen M: Wnt5a-Rac1-NF- $\kappa$ B homeostatic circuitry sustains innate immune functions in macrophages. J Immunol 192: 4386-4397, 2014.

269. D'Amico L, Mahajan S, Capietto AH, Yang Z, Zamani A, Ricci B, Bumpass DB, Meyer M, Su X, Wang-Gillam A, et al: Dickkopf-related protein 1 (Dkk1) regulates the accumulation and function of myeloid derived suppressor cells in cancer. J Exp Med 213: 827-840, 2016.

270. Staal FJ and Arens R: Wnt signaling as master regulator of T-lymphocyte responses: Implications for transplant therapy. Transplantation 100: 2584-2592, 2016.

271. Swafford D and Manicassamy S: Wnt signaling in dendritic cells: Its role in regulation of immunity and tolerance. Discov Med 19: 303-310, 2015.

272. Holtzhausen A, Zhao F, Evans KS, Tsutsui M, Orabona C, Tyler DS and Hanks BA: Melanoma-derived Wnt5a promotes local dendritic-cell expression of IDO and immunotolerance: Opportunities for pharmacologic enhancement of immunotherapy. Cancer Immunol Res 3: 1082-1095, 2015.

273. Hanks BA: Immune evasion pathways and the design of dendritic cell-based cancer vaccines. Discov Med 21: 135-142, 2016.

274. Kaur A, Webster MR and Weeraratna AT: In the Wnt-er of life: Wnt signalling in melanoma and ageing. Br J Cancer 115: 1273-1279, 2016.

275. Law NC, Weck J, Kyriss B, Nilson JH and Hunzicker-Dunn M: Lhcgrexpression in granulosacells: RolesforPKA-phosphorylated $\beta$-catenin, TCF3, and FOXO1. Mol Endocrinol 27: 1295-1310, 2013.

276. Liu Z and Habener JF: Glucagon-like peptide-1 activation of TCF7L2-dependent Wnt signaling enhances pancreatic beta cell proliferation. J Biol Chem 283: 8723-8735, 2008.

277. Bellei B, Pitisci A, Catricalà C, Larue L and Picardo M: $\mathrm{Wnt} / \beta$-catenin signaling is stimulated by $\alpha$-melanocyte-stimulating hormone in melanoma and melanocyte cells: Implication in cell differentiation. Pigment Cell Melanoma Res 24: 309-325, 2011

278. Furuyashiki T and Narumiya S: Stress responses: The contribution of prostaglandin E(2) and its receptors. Nat Rev Endocrinol 7: 163-175, 2011.

279. Brudvik KW, Paulsen JE, Aandahl EM, Roald B and Taskén K: Protein kinase A antagonist inhibits $\beta$-catenin nuclear translocation, c-Myc and COX-2 expression and tumor promotion in Apc(Min/+) mice. Mol Cancer 10: 149, 2011.

280. Jansen SR, Holman R, Hedemann I, Frankes E, Elzinga CR, Timens W, Gosens R, de Bont ES and Schmidt M: Prostaglandin $E_{2}$ promotes $M Y C N$ non-amplified neuroblastoma cell survival via $\beta$-catenin stabilization. J Cell Mol Med 19: 210-226, 2015.

281. Estus TL, Choudhary S and Pilbeam CC: Prostaglandinmediated inhibition of PTH-stimulated $\beta$-catenin signaling in osteoblasts by bone marrow macrophages. Bone 85: 123-130, 2016. 